FEDERAL RESERVE BANK OF SAN FRANCISCO

WORKING PAPER SERIES

\title{
The Effect of Capital Controls and Prudential FX Measures on Options-Implied Exchange Rate Stability
}

\author{
Marius del Giudice Rodriguez, \\ Federal Reserve Bank of San Francisco \\ Thomas Wu, UC Santa Cruz
}

May 2013

Working Paper 2013-20

http://www.frbsf.org/publications/economics/papers/2013/wp2013-20.pdf

The views in this paper are solely the responsibility of the authors and should not be interpreted as reflecting the views of the Federal Reserve Bank of San Francisco or the Board of Governors of the Federal Reserve System. 


\title{
The Effect of Capital Controls and Prudential FX Measures on Options-Implied Exchange Rate Stability*
}

\author{
Marius del Giudice Rodriguez ${ }^{\dagger}$ \\ Federal Reserve Bank of San Francisco
}

\author{
Thomas $\mathrm{Wu}^{\ddagger}$ \\ UC Santa Cruz
}

May 2013

\begin{abstract}
Has the recent wave of capital controls and prudential foreign exchange (FX) measures been effective in promoting exchange rate stability? We tackle this question by studying a panel of 25 countries/currencies from July 1, 2009, to June 30, 2011. We calculate daily measures of exchange rate volatility, absolute crash risk, and tail risk implied in currency option prices, and we construct indices of capital controls and prudential FX measures taking into account the exact date when policy changes are implemented. Using a difference-in-differences approach, we find evidence that (i) tightening controls on nonresidents suppresses daily exchange rate fluctuations at the cost of increasing the frequency of outliers, (ii) easing controls on residents truly improves exchange rate stability over all dimensions, and (iii) tightening prudential FX measures not specific to derivative markets reduces absolute crash risk and tail risk, with no effect on volatility.

Keywords: Exchange Rates, Volatility, Crash and Tail Risk, Currency Options, Capital Controls, Prudential Measures.

JEL Codes: F31, F32, G13, G15.
\end{abstract}

\footnotetext{
${ }^{*}$ Tim Moos, Jeremy Pearce, and Talia Smith provided excellent research assistance for this project. The authors would like to thank Craig Hakkio, Michael Melvin, Jen Poole, and seminar participants at the Central Bank of Brazil, University of Toronto, West Coast Workshop on International Finance and Open Economy Macroeconomics at Santa Clara University, XXX Encuentro de Economistas del Banco Central de Reserva del Perú, BlackRock, Federal Reserve Bank of Kansas City, FGV-EESP, EMG Workshop on International Capital Flows and the Global Economy at City University of London, and University of Hawaii.

${ }^{\dagger}$ The views in this paper are solely the responsibility of the authors and should not be interpreted as reflecting the views of the Federal Reserve Bank of San Francisco or the Board of Governors of the Federal Reserve System. E-mail: marius.rodriguez@sf.frb.org.

${ }^{\ddagger}$ Economics Department, 465 E2 Building, Santa Cruz, CA 95064. E-mail: thomaswu@ucsc.edu.
} 


\section{Introduction}

Do macroeconomic policies designed to curb the volatility of a given variable necessarily make it more stable? Not always. In some cases, daily fluctuations may become less volatile at the cost of increasing the frequency of outliers. ${ }^{1}$ In this paper, we show that this is the case for certain types of controls on cross-border capital flows and their effects on exchange rates.

Despite their long (and renewed) popularity, the benefits of capital controls and prudential foreign exchange (FX) measures remain elusive. Two comprehensive surveys of the literature conclude that capital controls "have had little power to stop speculative attacks on regimes that were seen by the market as inconsistent" (Dooley, 1997, p. 677) and that "empirical analysis has failed to yield conclusive results" (Eichengreen, 2001, p. 341). Glick and Hutchison (2005) and Glick, Guo, and Hutchison (2006) analyze a sample of 160 currency crises from 1975 to 1997 and conclude that capital controls do not insulate countries from such problems. In fact, they find that the likelihood of currency crisis is lower in more financially open economies. Binici, Hutchison, and Schindler (2011) show that the effects of capital controls vary markedly across the types of capital controls, both by asset categories, by the direction of flows, and across countries' income levels. More recent studies have switched the focus from periods of net capital outflows to periods of net capital inflows. Ostry et al. (2010, 2011) explore the circumstances under which there seems to be a rationale for adopting capital controls and prudential measures as part of the policy response to surges in capital inflows. On the empirical side, Qureshi et al. (2011, p. 2) find evidence "suggesting that capital controls and prudential measures can indeed reduce financial fragilities," while Habermeier, Kokenyne, and Baba (2011) document the experience of four emerging markets during the 2000s as a "mixed success."

In this paper, we shed additional light on the topic in a couple of new ways. First, we study the effects of capital controls and prudential FX measures on market participants' expectations regarding the distribution of future exchange rate movements. In particular, we focus on three

\footnotetext{
${ }^{1}$ Taleb and Blyth (2011, p. 33) criticize "the artificial suppression of volatility - the ups and downs of life - in the name of stability". According to the authors, "[i]t is both misguided and dangerous to push unobserved risks further into the statistical tails of the probability distribution of outcomes and allow these high-impact, low-probability 'tail risks' to disappear from policymakers' fields of observation."
} 
key aspects of these distributions: One dimension is given by daily fluctuations, and is generally referred to as "volatility"; the second dimension is given by a large probability of a sudden correction in one particular direction (for instance, a currency that is overvalued suddenly depreciating), which we will refer to as "absolute crash risk"; and the final dimension relates to the probability of observing outliers, commonly referred to as "tail risk." We construct daily measures of implied volatility, absolute crash risk, and tail risk based on the second, (absolute value of the) third, and fourth moments, respectively, of risk-neutral probability density functions extracted from currency options.

Second, we acknowledge that the recent wave of policies aimed at curbing the destabilizing effects of large capital flows has been typically implemented through gradual steps. For instance, Turkey increased the required reserve ratio for foreign currency liabilities from $9 \%$ to $9.5 \%$ on April 30, 2010, then from $9.5 \%$ to $10 \%$ on August 6, 2010, and finally from $10 \%$ to $11 \%$ on October 1, 2010. Other examples of sequential adjustment in policy tools can be found in the Financial Operations Tax (IOF) in Brazil or the reserve requirements for foreign currency liabilities in India and Russia. These gradual changes are not captured by existing de jure indices, which use as inputs binary indicators reflecting the presence (or absence) of a given control or prudential measure, thereby rendering them ill-suited for our purposes. To overcome this challenge, we use the International Monetary Fund's (IMF) Annual Report on Exchange Arrangements and Exchange Restrictions (AREAER) to compile daily country indices, which calculate the cumulative number of relevant policy changes implemented by each individual country over the sample period.

Third, we analyze a sample of countries that experienced large net capital inflows in the aftermath of the 2008 global financial crisis. The two-speed world economic recovery that followed the crisis - unimpressive in the United States, Europe, and Japan, but stronger in other smaller advanced countries and emerging markets - divided central banks into very different policy stances. On one side, the Federal Reserve, the Bank of England, the European Central Bank, and the Bank of Japan with near-zero policy rates and unprecedented levels of monetary expansion. On the other side, smaller advanced countries and emerging markets 
with positive policy rates, which appeared more appropriate given the stage of their business cycles. Investors naturally fled liquidity-exporting countries in search of higher yields. Wary of the potentially destabilizing effects of surges in capital inflows, policymakers in some of the liquidity-importing countries again resorted to policies aimed at discouraging foreign currency inflows and creating a macroprudential liquidity buffer. We believe this backdrop provides a favorable setup for identification. Specifically, we use the fact that not all countries experiencing surges in capital inflows implemented capital controls or prudential FX measures during the sample period as an opportunity to apply a difference-in-differences approach.

We combine both data sets into a daily panel of 25 countries/currencies quoted against the U.S. dollar (USD) from July 1, 2009, until June 30, 2011. ${ }^{2}$ Our treatment group includes 12 liquidity-importing countries that implemented policy changes during our sample period (Brazil, China, Colombia, India, Indonesia, Israel, Philippines, Russia, South Africa, South Korea, Thailand, and Turkey), and our control group includes 13 liquidity-importing countries that did not experience any relevant regulatory change in capital controls or prudential measures (Australia, Canada, Czech Republic, Denmark, Hungary, Malaysia, Mexico, New Zealand, Norway, Poland, Singapore, Sweden, and Switzerland). We find empirical evidence that the tightening of capital controls on nonresidents creates an illusory stability gain: it suppresses daily exchange rate fluctuations but at the cost of increasing the likelihood of currency crisis and with no clear effect on absolute crash risk. ${ }^{3}$ Notwithstanding, our results also suggest that the easing of capital controls on residents truly improves exchange rate stability, as it significantly reduces the volatility, the asymmetry, and the "thickness" of the distribution tails of expected exchange rate changes over the short, medium, and long terms. Finally, we show that the tightening of prudential FX measures that are not specific to derivative markets reduces absolute crash risk and tail risk with no significant effect on volatility.

This is not the first paper to study the contrasting effects of macroeconomic policies on normal and more extreme types of exchange rate fluctuations. Engel and Hakkio (1993) analyze target zones in the context of the European Monetary System (EMS). They find that

\footnotetext{
${ }^{2}$ These are the 25 major currencies traded against the USD with the exception of the liquidity exporters, which are the euro (EUR), the Brittish pound sterling (GBP), and the Japanese yen (JPY).

${ }^{3}$ This result is along the lines of Glick and Hutchison (2005) and Glick, Guo, and Hutchison (2006).
} 
exchange rates in a target zone are subject to extreme volatility around times of realignment, which is not the case for exchange rates in a floating regime. The same authors observe that "EMS exchange rates have more outliers than floating exchange rates, but EMS outliers are less volatile than floating rate outliers" (Engel and Hakkio, 1996, p. 56). Our paper also relates to several studies on carry trade and crash and tail risks, such as Jurek (2007), Brunnermeier, Nagel, and Pedersen (2008), and Chernov, Graveline, and Zviadadze (2012). However, our paper is the first to show that capital controls affect different dimensions of exchange rate risk in different - and sometimes opposing - ways.

The rest of the paper is organized in the following way. Section 2 discusses the extraction of probability density functions from currency options and presents our measures of implied volatility and tail risk. Section 3 explains the construction of our indices of policy changes in capital controls and prudential FX measures. Section 4 describes the empirical strategy. Section 5 presents the estimation results. Finally, Section 6 concludes.

\section{Measures of Exchange Rate Stability}

\subsection{Recovering Risk-Neutral Probability Density Functions}

The FX derivative market is one of the largest and most liquid in the world. Regarding its magnitude, the Bank for International Settlements (BIS) reported in June 2012 that roughly USD 67 trillion in notional over-the-counter derivatives are outstanding globally. ${ }^{4}$ With a large number of contracts and market participants, it is safe to argue that derivative prices should reflect investors' views concerning the distribution of the underlying assets.

Under a general set of assumptions, finance theory dictates that the price of any asset should equal the discounted expected value of its future cash flows. Moreover, the expected value is taken over the risk-neutral density. Since the cash flows from a derivative transaction are a direct function of the price of the underlying asset, its price must take into account the asset's distribution. Breeden and Litzenberger (1978) were the first to show how one could back out the risk-neutral density of price moves from a set of derivative prices. More precisely,

\footnotetext{
${ }^{4}$ See BIS (2012).
} 
the authors demonstrate that, by differentiating derivative prices with respect to the price of the underlying asset, one can obtain the probability density function. To illustrate this point, the value of a call option is the expected value of its payoff on the expiration date $T$ discounted back to the present. So, if $C$ is the price of a call option, we have ${ }^{5}$

$$
C=\int_{-\infty}^{\infty} e^{-r T} \max \left\{S_{T}-X, 0\right\} f\left(S_{T}\right) d S_{T}=\int_{X}^{\infty} e^{-r T}\left(S_{T}-X\right) f\left(S_{T}\right) d S_{T}
$$

where $X$ is the strike price, $r$ is the risk-free interest rate, $S_{T}$ is the spot price at maturity and $f\left(S_{T}\right)$ represents the risk-neutral probability function of the price of the underlying asset. The second derivative of $C$ is then

$$
\frac{\partial^{2} C}{\partial X^{2}}=e^{-r T} f(X)
$$

By rearranging:

$$
f(X)=e^{r T} \frac{\partial^{2} C}{\partial X^{2}}
$$

Therefore, based on equation (3), if one wishes to obtain the value of the risk-neutral density, a continuum of strike prices is necessary. In reality however, such data are unavailable, and one needs to resort to an interpolation scheme that builds on existing prices. Within the context of options on FX markets, Malz (1997) proposes an interpolation methodology that builds on the most common traded securities within the asset class. The author argues that traders in this market demonstrate a desire to deal with securities that exploit specific features of the risk-neutral densities. Most of these securities are redundant in that they are linear combinations of canonical securities like call and put options. The straddle, risk reversal, and strangle appear to be the most common instruments, which we will briefly describe.

In this paper, we follow Malz (1997) by focusing on two strategies: risk reversal $(r r)$ and strangle $(s t r)$. We demonstrate that the combination of these strategies with an at-the-money option allows one to uncover option prices across a set of strikes. ${ }^{6}$

\footnotetext{
${ }^{5} \mathrm{~A}$ general and well-known market convention is that option prices are usually quoted in terms of implied volatilities as backed out from the Black-Scholes formula.

${ }^{6}$ In the option market literature, such linkage between option and strike prices is usually referred as the
} 
Risk reversals are strategies that combine a long position in out-of-the-money calls (puts) with a short position in out-of-the-money puts (calls). The options share the same maturities and deltas. ${ }^{7}$ The goal of this strategy is to explore the fact that, unlike the Black-Scholes formula, exchange rates deviate from the lognormal distribution. Therefore, the investor can profit when prices move significantly.

Finally, in a strangle the investor takes long positions in out-of-the-money calls and puts with same maturities and deltas. The investor can, in this case, profit when prices increase or decrease significantly. Strangle prices share a unique feature in that they are quoted as a spread from at-the-money option prices.

We let $\sigma^{(0.75)}$ and $\sigma^{(0.25)}$ represent the 25-delta put and call options respectively, and let atm $_{t}$ be the implied volatility of the at-the-money option. ${ }^{8}$ Therefore, we arrive at the following system of equations based on the discussion above:

$$
\begin{aligned}
r r_{t} & =\sigma_{t}^{(0.25)}-\sigma_{t}^{(0.75)} \\
s t r_{t} & =0.5\left(\sigma_{t}^{(0.25)}+\sigma_{t}^{(0.75)}\right)-a t m_{t} .
\end{aligned}
$$

By rearranging equations (4) and (5), we can find the implied volatilities as a function of the priced strategies:

$$
\begin{aligned}
& \sigma_{t}^{(0.25)}=a t m_{t}+s t r_{t}+0.5 r r_{t} \\
& \sigma_{t}^{(0.75)}=a t m_{t}+s t r_{t}-0.5 r r_{t} .
\end{aligned}
$$

Equations (6) and (7) display the implied volatilities for a given set of deltas. It is clear from this discussion, that we can only uncover the implied volatilities at points for which we have observed prices. In most cases, this happens only on a small set of points, and in order to get a continuum of prices we need to make use of some interpolation scheme. To do so,

\footnotetext{
volatility smile.

${ }^{7}$ The option deltas are used to describe the moneyness of the option - a measure of how far current prices are from observed strike prices.

${ }^{8}$ All the analysis for 25-delta options can be applied for different deltas as well. In such case, one would need the prices of strategies, which are obviously dependent on a corresponding set of deltas.
} 
we use two approaches that have been used elsewhere in the literature. In the first case, we follow Malz (1997) and assume the following specification:

$$
\widehat{\sigma}_{\delta}(\delta)=b_{0} a t m_{t}+b_{1} r r_{t}(\delta-0.5)+b_{2} s t r_{t}(\delta-0.5)^{2} .
$$

In this case, the volatility smile can be decomposed into three components. The first two are just linear functions of the at-the-money option and the risk reversal accounting from deviations from 0.5 delta. The last component is a quadratic function of the strangle and deviations from the 0.5 delta. The form is very simple, and each of the components attempts to capture features of the volatility smile. More precisely, the at-the-money option, the risk reversal and the strangle capture the level, the skew, and the curvature in the volatility smile, respectively. To get the parameters $b_{0}, b_{1}$, and $b_{2}$, one just needs to make sure that the implied volatilities at observed data match exactly. For a 0.25 delta, the parameter vector $\left(b_{0}, b_{1}, b_{2}\right)$ equals $(1,-2,16) \cdot{ }^{9}$

Although rather simple, the above method lacks a financial interpretation. To address this issue, Castagna and Mercurio (2007), building on the work of Lipton and McGhee (2002), devised the vanna-volga method for FX options based on a replicating portfolio argument. More precisely, prices of nontraded options can be recovered through a static hedge strategy that matches all partial derivatives up to the second order. ${ }^{10}$ By adding the higher moments into the hedging exercise, they demonstrate that one needs to have prices for options with at least three different strike prices. Therefore, for an option with maturity $T$, the implied volatility at strike $X$ is approximately related to the implied volatilities of three other traded options with the same maturity and strikes $X_{1}<X_{2}<X_{3}$ through:

$$
\widehat{\sigma}(X, T) \approx \frac{\ln \frac{X_{2}}{X} \ln \frac{X_{3}}{X}}{\ln \frac{X_{2}}{X_{1}} \ln \frac{X_{3}}{X_{1}}} \sigma\left(X_{1}, T\right)+\frac{\ln \frac{X}{X_{1}} \ln \frac{X_{3}}{X}}{\ln \frac{X_{2}}{X_{1}} \ln \frac{X_{3}}{X_{2}}} \sigma\left(X_{2}, T\right)+\frac{\ln \frac{X}{X_{1}} \ln \frac{X}{X_{2}}}{\ln \frac{X_{3}}{X_{1}} \ln \frac{X_{3}}{X_{2}}} \sigma\left(X_{3}, T\right) .
$$

\footnotetext{
${ }^{9}$ See Malz (1997) for further details.

${ }^{10}$ All the sensitivities of option prices to underlying distributional and contract parameters are known as the option "Greeks." The option volga, for example, is the sensitivity of the option price to the diffusion term of the process for the underlying asset. One can build a volga neutral portfolio by computing portfolio weights that make the portfolio volga equal zero.
} 
The above methodology, however, is agnostic about the implied volatilities lying outside the $\left[X_{1}, X_{3}\right]$ interval. To mitigate this issue, we follow Jurek (2007) and append flat implied volatility tails beyond the last observed prices.

Once we have a set of option prices for a continuum of strikes, we calculate the moments of the distribution directly using the methodology advocated by Bakshi, Kapadia, and Madan (2003) and use them in our robustness check. ${ }^{11}$

\subsection{Currency Options-Implied Density Functions}

We collect daily spot and derivative prices for 25 currencies quoted against the USD from Bloomberg. The derivative prices include forwards and at-the-money straddles, 25-delta riskreversals, and 25-delta strangles, as well as forward rates, with maturities of 3, 6, and 12 months, from July 1, 2009, to June 30, 2011. We also obtain daily USD LIBOR interest rates from Bloomberg for the same maturities over the same sample period. We apply the above methodology to our data set and calculate daily risk-neutral probability density functions (PDF) for each country/currency and for each tenor (3, 6, and 12 months).

\section{[Insert Figures 1 to 3 about here]}

Figures 1 to 3 present some sample PDFs. Figure 1 plots three PDFs for expected percent changes of the Canadian dollar (CAD) against the USD (a positive expected percent change implies that the CAD is expected to depreciate relative to the USD) using currency options of 3-, 6-, and 12-month maturities, on March 1, 2010. The different shapes of the PDFs reflect the increasing uncertainty embedded in expectations over longer horizons. Figure 2 compares options-implied PDFs again for expected percent changes of the CAD against the USD over the 3-month period, this time using prices from three different days: our reference day, March 1, 2010; one relatively calm day, March 19, 2010; and one relatively turbulent day, May 20, 2010. While the time difference between the calm and turbulent days is less than one quarter, it was within that quarter that the Greek debt crisis hit the radar, which explains the very

\footnotetext{
${ }^{11}$ However, our empirical results are qualitatively the same regardless of whether we compute the moments following Malz (1997) or the vanna-volga method.
} 
different shapes of the PDFs. Figure 3 provides a constrast between 3-month options-implied PDFs of the CAD and the currency of another developed economy, Australia (AUD), and the currencies from some emerging markets: Russia (RUB), India (INR), Brazil (BRL), and South Africa (ZAR). The figure shows no clear distinction between emerging and developing countries. Some PDFs are thinner while some are fatter, obviously reflecting different institutional characteristics such as exchange rate regime flexibility or degree of financial openness. And in the cases of Brazil and Australia, the PDFs are almost identical.

\section{[Insert Tables 1 to 3 about here]}

Using the daily options-implied PDFs for each of the 25 currencies in our sample from July 1, 2009, to June 30, 2011, we calculate daily time series of implied volatility (given by the standard deviation of each PDF), implied crash risk (given by the skewness of each PDF), and implied tail risk (given by the kurtosis of each PDF). Tables 1 to 3 present some summary statistics regarding the different dimensions of exchange rate stability over the three time horizons we have chosen: 3,6 , and 12 months. The tables reveal that emerging markets dominate both extremes of the exchange rate implied volatility spectrum: the top three countries with largest average implied volatility are Hungary, Poland, and South Africa, and the bottom three countries are China, Thailand, and Singapore. This result is not surprising. For one, emerging markets are more susceptible to external shocks. Furthermore, it is more common to observe fixed or managed floating exchange rate regimes in these countries. Regarding to the symmetry of the PDFs, in almost all countries the probability of a significant depreciation against the USD is larger than that of an appreciation, with the largest average values of implied skewness being observed in South Korea, Russia, Mexico, Brazil, and Indonesia (although not always in this particular order). The only two countries that registered negative average implied skewness over the sample period were China $(-0.7,-0.5$, and -0.3 over the 3-, 6-, and 12-month horizons, respectively) and Switzerland for the 6- and 12-month horizons (-0.1 in both cases). Finally, outliers are more frequent in emerging markets (China, Indonesia, and Russia over 3 months; Indonesia, Russia, and Brazil over 6 months; and Indonesia, Russia, and South Korea over 12 months), while all countries with the lowest levels of implied 
tail risk are developed (Norway, Switzerland, and Japan).

\section{Capital Controls and Prudential FX Measures}

\subsection{Definition of Relevant Policy Changes}

We use the IMF's AREAER to compile two indices of policy changes in de jure capital controls and prudential FX measures for each individual country in our sample. ${ }^{12}$ As already mentioned in the introduction, our motivation for the construction of such indices is to gauge the effectiveness of policies aimed at curbing potentially destabilizing effects of large portfolio inflows. Hence, our capital control index only includes policy changes aimed at easing or tightening restrictions on cross-border financial transactions typically associated with speculative "hot money," that is, when the investment decision does not involve a lasting economic interest in the management of the enterprise concerned. ${ }^{13}$ For instance, equity shares and fixedincome securities such as bonds, bills, short-term government paper, bankers' acceptances, commercial paper, interbank deposits, and repurchase agreements. For similar reasons, we also disregard policy changes that only affect the reinvestment of dividends or earnings. We further distinguish among policies imposed explicitly to affect the absolute size of transactions (quantity-based), the timing of transactions (time-based), or the returns of transactions (price-based), as well as between restrictions on nonresidents' ability to invest in domestic assets and restrictions on residents' ability to invest in foreign assets. For instance, South Africa's increase in the foreign capital allowance limit of domestic agents from ZAR 2 million to ZAR 4 million on October 27, 2009, is an example of a quantity-based capital control easing on residents. Indonesia's imposition of a one-month minimum holding period for foreign purchases of Bank Indonesia Certificates (SBIs) on July 7, 2010, and subsequent increase from one to six months on May 13, 2011, are two examples of time-based capital control tightening

\footnotetext{
${ }^{12}$ The AREAER provides, among other things, a comprehensive description of controls on capital transactions and measures implemented in the financial sector, including prudential measures, from all member countries.

${ }^{13}$ Investment for the purpose of producing goods and services and, in particular, to allow investor participation in the management of an enterprise is considered direct investment. Controls on such transactions are not included in our capital control index. Controls on real estate transactions, personal capital transactions, and credit operations are also not included.
} 
on nonresidents. Brazil's $2 \%$ IOF tax rate on foreign investors' purchase of fixed-income instruments introduced on October 19, 2009, and its subsequent increase to $4 \%$ on October 10, 2010, and then to $6 \%$ on October 19, 2010, are three examples of price-based capital control tightening on nonresidents.

Prudential FX measures, in turn, encompass policy changes that are aimed not at controlling capital flows per se, but at controlling the exchange rate risk arising from such capital flows on the balance sheets of financial institutions. Typical prudential FX measures also tend to differ operationally from capital controls as they restrict holdings of foreign assets or liabilities by imposing limits on the relative composition of portfolios, rather than their absolute size. We differentiate between prudential FX measures that apply exclusively to FX derivatives (limits to unhedged foreign currency position, limits to FX derivatives trading as percentage of real transactions being hedged, reserve requirement for foreign exchange derivative transactions by nonresidents, and restrictions on the use of certain securities for margin purposes) and measures that apply to other FX assets and liabilities (cash reserve requirements, statutory liquidity ratios, loan-to-value ratios, safe asset holding ratios, and limits to net open positions). For instance, South Korea's imposition of a limit to corporate clients' derivatives trading at $125 \%$ of real transactions (import and export) being hedged on January 1, 2010, and further reduction from $125 \%$ to $100 \%$ on August 1, 2010, are two examples of tightening of prudential FX measures specific to derivative markets. Examples of tightening of prudential FX measures of other FX assets and liabilities can be found in Indonesia, which raised the reserve requirement on deposit accounts in foreign exchange from $1 \%$ to $5 \%$ on March 1, 2011, and then from 5\% to $8 \%$ on June 1, 2011.

\subsection{Policy Changes Over Time and Across Countries}

Applying the criteria described above, we identify a total of 60 relevant policy changes in capital controls and prudential FX measures over the course of our sample period, from July 1, 2009, to June 30, 2011. Table 4 reveals that, rather than being evenly distributed across the 25 countries in our sample, almost all policy changes were implemented by emerging economies, 
with the single exception being Israel's tightening of one prudential FX measure January 27, 2011. The other 59 policy changes are divided among Brazil, with twelve; China, with two; Colombia, with five; India, with five; Indonesia, with six; Philippines, with one; Russia, with five; South Africa, with seven; South Korea, with eight; Thailand, with five; and Turkey, with three. Table 4 also shows that there are $50 \%$ more policy changes in prudential FX measures than in capital controls (36 versus 24 ). Out of the 36 policy changes in prudential FX measures, 10 are specific to FX derivatives, and the majority tightened rather than eased the regulatory framework (27 versus 9). With respect to capital controls, changes in quantity-based controls are more popular than price-based, while time-based controls are the least popular (12, 10, and 2 policy changes, respectively). Additionally, changes in controls on nonresidents are more common than controls on residents (14 versus 10). Finally, changes in capital controls are split exactly between tightening and easing measures (12 each), but with most of the easing policy changes occurring through controls on residents (9).

\section{[Insert Table 4 about here]}

Policy changes are not evenly distributed over time either. Figure 4 shows the number of policy changes in capital controls on nonresidents (blue columns) and residents (red columns) in each month of our sample period and reveals two main clusters: a smaller one from August to November 2009 and a larger one from July 2010 to January 2011. Curiously, the clusters and their number of policy changes coincide with both the timing and magnitude of peaks in the time series of Google search volume index (SVI) for the term "quantitative easing." ${ }^{14}$ This high correlation reinforces the idea that most countries that implemented capital controls did so (or claimed to have done so) as a response to the distortions generated by the large-scale asset purchase programs of the Federal Reserve, European Central Bank, Bank of Japan, and Bank of England. Figure 5 presents a similar picture for the number of policy changes in prudential measures specific to FX derivatives (green columns) and other FX assets and liabilities (purple columns). Although policy changes in prudential FX measures are more

\footnotetext{
${ }^{14}$ Google SVI for a particular search term represents the search traffic for the term relative to the total number of searches on Google in a given time period. Hence, an increase in Google SVI implies that the search term is becoming more popular.
} 
spread out over the two years of our sample period, there is a clear peak in the number of changes implemented in the second half of 2010, which once again coincides with the peak in Google SVI for "quantitative easing."

\section{[Insert Figure 4 and 5 about here]}

\subsection{Construction of Indices}

The capital control index, $C C I_{i t}$, and prudential FX measure index, $P M I_{i t}^{F X}$ calculate the cumulative number of relevant policy changes implemented by each individual country over the sample period. Each country is assigned a value of zero in the first day of our sample period, July 1, 2009, and changes that tighten capital controls or prudential regulations add a value of one to the respective cumulative index on the day they become effective, while changes that ease capital controls or prudential regulations subtract a value of one. ${ }^{15}$ As a result, our indices are not simply on/off indicators of the presence of restrictions to cross-border financial transactions; they convey additional information about the intensity with which certain capital controls or prudential measures are being used by a country. Notwithstanding, the mapping is only indirect, as most policy changes are not perfectly comparable to each other with regards to their intensity levels. Let's take the case of India as an example. The cash reserve requirement (CRR), which is set at the same level for local and foreign liabilities, was increased from $5 \%$ to $5.5 \%$ on February 13, 2010, then increased to $5.75 \%$ on February 27, and finally to $6 \%$ on April 24, 2010. These policy changes are not uniform, but their intensities could be compared, since the first CRR raise is twice the absolute size of the other two subsequent increases. However, over the same period India also raised the statutory liquidity ratio (SLR) required for both domestic and foreign currency from $24 \%$ to $25 \%$ of net demand and time liabilities on October 27, 2009, and then lowered it back to $24 \%$ on December 18, 2010. Once again, we could argue that both the increase and decrease in SLR are of equal intensity, as both changes have the exact same absolute value. The issue, though, is how to compare the intensity of a $1 \%$

\footnotetext{
${ }^{15}$ Assigning a value of zero to all countries on the first day of the sample period does not preclude crosssection analysis with panel data. The inclusion of country-level fixed effects is sufficient to control for the initial variation on capital openness across countries.
} 
absolute change in SLR to a $0.25 \%$ or $0.5 \%$ absolute change in CRR, as both types of policy instruments are included in India's prudential FX measures index. To avoid the subjectivity inherent in such calls, we assign an absolute value of one to all prudential measures, using positive and negative signs to distinguish tightening from easing. In sum, $C C I_{i t}$ and $P M I_{i t}^{F X}$ are objective counts of the number of policy changes in de jure capital controls and prudential FX measures, respectively, for each country $i$ accumulated from July 1, 2009, up to day $t$.

Our new capital control and prudential FX measure indices have both advantages and disadvantages relative to indices from previous studies. First, they are based on rules and not on quantities affected by rules, which is the case of other de facto indices such as Edison and Warnock (2003) and Lane and Milesi-Ferretti (2007). Second, they differ from other objective de jure measures such as Chinn and Ito (2006, 2008), Glick and Hutchison (2005), and Schindler (2009), which are based on the average number of binary indicators on the existence of restrictions to different types of capital transactions. Although such de jure measures change when a new capital control is imposed on a relevant type of transaction, they remain constant when the intensity of an already existing control is changed. Third, our indices convey information regarding the intensity with which restrictions are being applied in an objective way, as opposed to resorting to subjective value judgment as in Quinn (1997) and Quinn and Toyoda (2008). Fourth, they are compiled at a daily frequency, which makes them uniquely suited to interact with daily data on financial market behavior. Finally, the major drawback of our indices is that different countries tend to like using their own set of policy tools, which are rarely directly comparable. Consequently, the coefficients estimated using our indices as regressors measure the average effect of the policy tools included within a category. ${ }^{16}$

\footnotetext{
${ }^{16}$ To make a baseball analogy, our indices count the number of hits, not the number of runs, from a team in each game. The number of runs maps more directly into the probability of winning a game. However, if such a statistic was not available, an econometrician could estimate the probability of winning a game given the number of hits.
} 


\section{Empirical Strategy}

Using a daily panel of 25 countries/currencies from July 1, 2009, until June 30, 2011, we estimate the following equations:

$$
\begin{aligned}
\text { volatility }_{i t}^{\tau} & =\sum_{p} \gamma_{1}^{\tau, p} C C I_{i t}^{p}+\sum_{q} \gamma_{2}^{\tau, q} P M I_{i t}^{q}+\vec{\gamma}_{3}^{\tau} \text { time }_{t}+\vec{\gamma}_{4}^{\tau} \text { country }_{i}+\varepsilon_{i t}^{\tau} \\
\text { abs }\left(\text { crash risk }_{i t}^{\tau}\right) & =\sum_{p} \delta_{1}^{\tau, p} C C I_{i t}^{p}+\sum_{q} \delta_{2}^{\tau, q} P M I_{i t}^{q}+\vec{\delta}_{3}^{\tau} \text { time }_{t}+\vec{\delta}_{4}^{\tau} \text { country }_{i}+\nu_{i t}^{\tau} \\
\text { tail risk }_{i t}^{\tau} & =\sum_{p} \delta_{1}^{\tau, p} C C I_{i t}^{p}+\sum_{q} \delta_{2}^{\tau, q} P M I_{i t}^{q}+\vec{\delta}_{3}^{\tau} \text { time }_{t}+\vec{\delta}_{4}^{\tau} \text { country }_{i}+v_{i t}^{\tau} .
\end{aligned}
$$

We use as dependent variables proxies for three different dimensions of exchange rate stability extracted from currency options: implied volatility, absolute crash risk, and tail risk. Note that we use the absolute value of skewness and not skewness itself as the dependent variable. Although crash risk refers to a large positive skewness (that is, a distribution of expected future exchange rate changes skewed towards large depreciations), we believe that a distribution skewed towards large appreciations is also undesirable. From a policymaker's point of view, a more symmetric distribution is better than large asymmetry in any direction.

Each equation is estimated three times, each time using exchange rate implied volatility, absolute crash risk, and tail risk extracted from currency options of different tenors $(\tau=3,6$, and 12 months). We include as regressors our newly constructed series of cumulative policy changes in capital controls and prudential FX measures. We disaggregate capital controls according to the type of flows and location of the agent being restricted ( $p=$ price-based controls on nonresidents, quantity-based controls on nonresidents, time-based controls on nonresidents, quantity-based controls on residents) and prudential FX measures according to the type of FX market being affected ( $q=$ FX derivatives, other FX assets and liabilities). ${ }^{17}$

We include country fixed effects to control for omitted variables that vary across countries but not over time (such as differences in initial levels of capital openness or exchange rate regime choices) as well as time effects to control for omitted variables that vary over time

\footnotetext{
${ }^{17}$ In our sample we do not observe policy changes on price-based capital controls on residents nor on timebased capital controls on residents.
} 
but not across countries (such as changes in risk aversion of investors in the liquidity exporting countries, which could be proxied by the VIX). The inclusion of time and fixed effects combined with the fact that not all countries experienced relevant policy changes in capital controls or prudential FX measures allow us to interpret the coefficients associated with $C C I_{i t}^{p}$ and $P M I_{i t}^{q}$ as difference-in-differences estimators: They compare the average change in the dependent variable for the 12 countries in the treatment group (Brazil, China, Colombia, India, Indonesia, Israel, Philippines, Russia, South Africa, South Korea, Thailand, and Turkey) relative to the average change in the same variables for the 13 countries in the control group (Australia, Canada, Czech Republic, Denmark, Hungary, Malaysia, Mexico, New Zealand, Norway, Poland, Singapore, Sweden, and Switzerland).

One widely known issue with difference-in-differences (see Bertrand et al., 2004) and panel estimation with financial data in general (see Petersen, 2009) is that the OLS assumption that residuals are uncorrelated leads to biased standard errors. Specifically, the null hypothesis of no effect tends to be largely over-rejected for any given confidence level. To correct this bias, we calculate standard errors that account for two dimensions of within cluster correlation: correlation among different countries on the same date, and correlation between different dates in the same country. Intuitively, we are allowing financial shocks to affect multiple currencies at the same time and country specific shocks to be serially correlated.

The difference-in-differences approach helps prevent some of the main perils associated with single country studies. For instance, imagine a case in which a truly effective prudential FX measure is introduced in some countries at the same time as a major deterioration in global market conditions. The countries that implement the prudential FX measure experience increased exchange rate instability - although the increase is significantly smaller than for countries that did not implement the prudential FX measure. While single country studies would suggest that such policy has the opposite of the desired effect, the differencein-differences estimator would correctly identify its benefits. Alternatively, imagine a scenario in which some countries enact an innocuous policy change in capital control and, by chance, global financial market conditions substantially improve. While single country studies would 
tend to conclude that the policy change caused the improvement in exchange rate stability, difference-in-differences estimators would only suggest this if the reduction in volatility, absolute crash risk, or tail risk experienced by the treatment group were significantly larger in magnitude than that experienced by the control group.

In theory, countries from the control and treatment groups should be identical except in one aspect, the implementation of policy changes in capital controls and prudential FX measures (i.e., the adoption of the "treatment"). Unfortunately, this ideal setup is only available for controlled experiments. However, Figures 6, 7, and 8 reveal that the monthly behaviors of the outcome variables (implied volatility, absolute crash risk, and tail risk, respectively) over the 3-, 6-, and 12-month periods in the control and treatment groups are very similar, especially in the period preceding the implementation of policy changes. ${ }^{18}$ In Figure 6 , we plot the monthly average of implied volatility for the control group (blue line) and three different treatment groups: countries that on average have tightened capital controls on nonresidents (red line), countries that on average have eased capital controls on residents (green line), and countries that on average have tightened prudential FX measures not specific to derivatives markets (yellow line). All four series seem to move in a highly correlated manner: There is a long-run downward trend temporarily interrupted by short-run increases in implied volatility in the months of November 2009, May 2010, October 2010, and May 2011. However, there is an apparent change in behavior after the second half of 2010; the drop in implied volatility in all treatment groups is not accompanied by a proportional decrease in the control group. Curiously, that is exactly the same period when most policy changes are implemented (see Figures 4 and 5).

\section{[Insert Figure 6, 7, and 8 about here]}

Figure 7 and 8 show analogous pictures for the monthly average of the absolute crash risk and tail risk. In both cases, the behavior of the control group (blue line) is similar to that of the treatment groups up to the second half of 2010. After that period, countries that have

\footnotetext{
${ }^{18}$ As long as the time series evolution of the outcome variables (especially before most policy changes are implemented) are similar, changes in levels are not a problem, since they are captured by the fixed effects.
} 
tightened controls on nonresidents (red line) seem to experience an increase in both types of risk, countries that have eased controls on residents (green line) seem to experience a decrease, and countries that have tightened prudential FX measures not specific to derivatives markets (yellow line) continue to behave in a similar way to the control group.

\section{Estimation Output}

\subsection{Baseline Regressions}

There are three sets of three regressions in Table 5. Each set refers to results obtained using currency options of different tenors (3-, 6-, and 12-months, respectively). Within each set, each regression has a different dependent variable: implied volatility, or the standard deviation of the risk-neutral PDF; implied absolute crash risk, or the absolute value of the skewness of the risk-neutral PDF; and implied tail risk, or the kurtosis of the risk-neutral PDF, respectively. Once again, the dependent variables are in natural logs, so the estimated coefficients can be interpreted as semi-elasticities: they gauge the percent increase in each moment of the distribution resulting from a one-unit policy change (i.e., tightening) in capital controls or prudential FX measures.

\section{[Insert Table 5 about here]}

Table 5 reveals that capital controls on nonresidents, regardless of their type (price-, quantity-, or time-based) have qualitatively similar effects. First, the tightening of capital controls on nonresidents significantly reduces the implied volatility over all horizons, with the exception of quantity-based controls over the 12-month horizon, which is associated with a positive and statistically significant coefficient. The effect on implied volatility ranges from a reduction of $1.6 \%$ to $2.5 \%$ for price-based controls, a reduction of $14.5 \%$ to $23.8 \%$ for timebased controls, and a reduction of $31.3 \%$ to an increase of $8.5 \%$ for each unit of policy change. Second, there is no clear evidence of benefits associated with tightening capital controls on nonresidents with respect to absolute crash risk. When we focus on the 3-month horizon, the tightening of price-based controls on nonresidents reduces the absolute skewness of the 
exchange rate distribution, the tightening of quantity-based controls on nonresidents significantly increases it, and the tightening of time-based controls renders a nonsignificant coefficient. When we look at the 6- and 12-month horizons, all estimated coefficients associated with controls on nonresidents are not statistically significant. Third, with respect to implied tail risk, the pattern is very clear: all estimated coefficients associated with controls on nonresidents are positive and statistically significant, regardless of type and horizon. Moreover, the side effects on fourth moments have semi-elasticities comparable to the benefits on second moments. A one-unit increase in controls on nonresidents increases the implied tail risk by $1.5 \%$ to $2.0 \%$ for price-based controls, $17.4 \%$ to $43.1 \%$ for quantity-based controls, and $9.0 \%$ to $12.3 \%$ for time-based controls. All in all, our baseline regression suggests that the tightening of capital controls on nonresidents indeed reduces the implied volatility of exchange rates, but the gained stability in second moments comes at a cost of increased kurtosis, and with no clear benefits regarding absolute skewness. In other words, restrictions on the ability of nonresidents to hold domestic assets are associated with illusory exchange rate stability: they suppress daily fluctuations while increasing the likelihood of currency crisis, with no effect on crash risk.

While the gains from tightening controls on nonresidents are illusive, policies aimed at easing the ability of residents to hold foreign assets are a different story. Table 5 also shows that the estimated coefficients associated with capital controls on residents are positive and statistically significant for all equations (implied volatility, absolute crash risk, and tail risk) and over all horizons (3-, 6-, and 12-month), with the only exception being the coefficient associated with implied volatility over the 3-month horizon (which is not statistically significant). Given that our index codes the easing of capital controls on residents as negative values, these estimates imply that such policies are truly effective in rendering exchange rate stability: a one-unit policy change easing on controls on residents suppresses daily exchange rate fluctuations with a reduction on the implied standard deviation of $3.7 \%$ to $6.1 \%$; improves the symmetry of the distribution of expected exchange rate changes with a reduction on the absolute value of the implied skewness of $54.3 \%$ to $81.1 \%$; and decreases the likelihood of 
currency crises with a reduction of the implied kurtosis of $6.7 \%$ to $7.2 \%$.

Regarding prudential FX measures, empirical evidence fails to detect any statistically significant effect on implied volatility. Moreover, the tightening of prudential FX measures specific to FX derivatives affects the absolute skewness and kurtosis of the distribution of expected exchange rate changes in an opposite way when compared to the tightening of prudential FX measures of other FX assets and liabilities. Specifically, while tightening measures specific to FX derivatives significantly increases both absolute crash risk and tail risk, tightening measures on other FX assets and liabilities significantly reduces them. At first pass, these results suggest that policymakers should avoid tightening prudential FX measures specific to FX derivatives and focus on other FX assets and liabilities. Nevertheless, we must bear in mind that it is probably inadequate to gauge the effect of prudential FX derivatives measures on moments extracted from FX derivatives. Regulatory changes specific to trading practices in FX derivatives could affect the liquidity of such markets on the day they are implemented, which in turn could lead to changes in option prices even if market participants' expectations regarding future exchange rate movements remained unchanged. Hence, we limit ourselves to the analysis of prudential measures on other FX assets and liabilities: the effects of a one-unit tightening in such measures ranges from $17.7 \%$ to $21.7 \%$ on implied absolute crash risk and from $2.1 \%$ to $3.2 \%$ on implied tail risk.

\subsection{Disaggregation at Country Level}

Our first major concern regarding the interpretation of the results obtained from our baseline regressions relates to the cross-country aggregation of the capital control and prudential FX measure indices. Although we disaggregate capital controls by type of flows and location of agent being restricted and prudential FX measures by market, within each of these subcate-

gories policy changes from different countries are all coded equally with an absolute value of one. However, different countries rely on different specific policy tools, which are most often not directly comparable. To illustrate the potential problem this aggregation may cause, imagine a scenario in which four different countries ease controls on residents, but with different 
specific toolkits and different levels of intensity. Moreover, imagine that the policy changes are innocuous in three countries but very successful in one of them. If the beneficial effects of the policy change in the successful country are strong enough, our baseline regressions could report a statistically significant coefficient associated to the easing of controls on residents, which would lead us to naively conclude that easing such policies are generally effective. To check whether the results obtained from our baseline regressions are driven by exceptionally successful individual experiences, we reestimate equations (10), (11), and (12) using capital control and prudential FX measure indices, which are disaggregated at the country level. The resulting estimation output presented in Table 6 reveals that this is not the case. By and large, estimation output obtained from the experiences of individual countries clearly supports our previous interpretation.

\section{[Insert Table 6 about here]}

Table 6 shows that the estimated coefficients associated with the tightening of controls on nonresidents are almost all negative and statistically significant in the implied volatility equations, with the exception of China's quantity-based controls over the 12-month horizon (which is positive and significant); almost all positive and statistically significant in the implied tail risk equations, with the exception of Brazil's price-based controls over the 3-month horizon (which is not significant); and there is no clear pattern in the absolute crash risk equations, which are negative and significant for Brazil's price-based controls, positive and significant for China's quantity-based control over the 3-month horizon, and not significant for the remaining coefficients. Table 6 also confirms our previous reading that easing capital controls on residents renders a more symmetric and less leptokurtic distribution of future expected exchange rate changes over all horizons. With respect to second moments, easing capital controls also reduces volatility in most countries, especially over the 6 - and 12-month horizons, with the exception of Colombia, in which easing controls on nonresidents seems to increase volatility.

Individual country experiences with prudential FX measures specific to FX derivatives only provide a clear pattern in the tail risk equations, in which statistically significant coefficients are all positive. In the implied volatility and absolute crash risk equations, we find positive and 
significant, negative and significant, and not significant coefficients. Once again, we believe that it is ill-advised to draw any conclusion from these coefficients, since regulation specific to FX derivative markets creates noise in FX option prices. Finally, estimated coefficients associated with prudential FX measures for other FX assets and liabilities reinforce the idea that the tightening of such policies significantly reduces absolute crash risk and tail risk for all countries. Nonetheless, the results reveal some heterogeneity in the beneficial effects, which tend to be significant over all horizons for most countries but concentrated in the short run for Brazil, Indonesia, and South Africa. Regarding the effect of such policies on second moments, no clear pattern can be obtained from individual experiences, which combines some significantly positive, significantly negative, and not significant coefficients.

In sum, empirical evidence presented in this section obtained from individual country experiences yields the same conclusions from the baseline regressions using more aggregate capital control and prudential FX measure indices.

\subsection{Base Currency Effect}

The exchange rates of the 25 countries in our sample are all quoted against the USD. However, it is reasonable to expect the EUR to be the most natural choice of base currency for the European economies in our sample, given their stronger trade and financial linkages with the European Monetary Union. ${ }^{19}$ In this robustness check, we test whether the choice of base currency could be driving the results. For instance, imagine an alternative hypothesis in which capital controls and prudential FX measures have no significant effects on exchange rate volatility, crash risk, and tail risk, when the currencies are quoted against their natural base (i.e., USD for Latin American and Asian economies, EUR for European economies). However, when we force European economies to be quoted against the USD, we add another layer of risk from the effects of the Greek debt crisis on the EUR/USD exchange rate. Under this alternative story, if the number of European countries is unevenly distributed between the treatment and control groups, the null hypothesis of no effect could be rejected. In

\footnotetext{
${ }^{19}$ None of the European countries in our sample belongs to the European Monetary Union. We excluded the Euro area and its currency from our sample since the ECB is one of the central banks implementing a quantitative easing type policy. In other words, the region as a whole is a "liquidity exporter."
} 
particular, if there are more European countries in the control group than in the treatment group (and since the European countries are experiencing an increase in volatility due to the base currency conversion), then our baseline regressions could mislead us to conclude that the treatment is effective in reducing volatility. Going back to Table 4, we can see that this alternative story is a plausible concern. Out of the nine European countries in our sample, only two have implemented any sort of policy change in capital controls or prudential FX measures. Specifically, only Russia and Turkey are in our treatment group.

\section{[Insert Table 7 about here]}

We check whether the choice of the USD as base currency for European economies is driving our results by re-estimating our baseline regressions restricting the sample to only include non-European countries. The estimation results presented in Table 7 do not support this alternative hypothesis. The estimated coefficients are qualitatively similar to the ones reported in Table 5 in magnitude, sign, and significance.

\subsection{Emerging Markets and Selection Bias}

As Table 4 highlighted, almost all countries in the treatment group are emerging markets. Out of the nine developed countries in our sample, only one belongs to the treatment groupIsrael, which tightened prudential FX measures. The uneven distribution of emerging markets between the control and treatment groups suggests that institutional factors might play an important role in the adoption of treatment. This raises the potential concern for selection bias: What we interpret as the effect of policy changes is in fact the effect of different institutional setups. In our specific case, emerging market currencies tend to be less stable - our analysis of Tables 1, 2, and 3 revealed that emerging markets have the highest observed average levels

of volatility, skewness, and kurtosis for all time horizons during the sample period. Hence, if there are more emerging markets in the treatment group, selection bias could lead us to the conclusion that capital controls and prudential FX measures have the opposite of the desired effect. 
One way to double-check whether selection bias is indeed an issue is by comparing the behavior of the outcome variables in both control and treatment groups. Our analysis of Figures 6,7 , and 8 showed very similar time series evolutions, especially before most policy changes are implemented, which suggests that the control group does provide a sensible counterfactual. Another way to control for selection bias is suggested by Angrist and Pischke (2008). The authors argue that if the researcher possesses knowledge of institutional factors that may influence the adoption of treatment, then he/she should restrict the sample using such information. In other words, if the distinction between emerging markets and developed countries is a decisive factor in the adoption of capital controls and prudential FX measures, then we should simply re-estimate our baseline regression restricting the sample to only include emerging markets.

\section{[Insert Table 8 about here]}

Table 8 reports the estimation output. Some of the effects seem quantitatively weaker. The most pronounced change is observed on the effects of a one-unit ease of controls on residents. In our baseline regression, the reduction of implied kurtosis of the distribution of future expected exchange rate changes ranges from $6.7 \%$ to $7.2 \%$ and the reduction of absolute skewness, from $54.3 \%$ to $81.1 \%$. But once we restrict the sample to emerging markets, those effects range from $4.2 \%$ to $4.6 \%$ and from $24.5 \%$ to $53.9 \%$, respectively. However, in qualitative terms, all main conclusions from our baseline regressions remain. Tightening of controls on nonresidents still provide an illusory sense of stability: the reduction in exchange volatility comes at a cost of increasing tail risk. Easing controls on residents is still associated with exchange rate stability by reducing volatility, absolute crash risk, and tail risk over almost all horizons. Finally, tightening prudential FX measures which are not specific to FX derivatives significantly reduce tail risk.

\subsection{Different Methods of Extracting Risk-Neutral Moments}

In this section we check whether our results are specific to our method of computing moments of the risk-neutral densities extracted from currency option prices. Specifically, we re-estimate 
our baseline regressions using as dependent variables measures of implied volatility, absolute crash risk, and tail risk calculated using the Vanna-Volga method. As we have explained in Section 2, the main difference between the Malz method and the Vanna-Volga method relies on the shape of the volatility smile. While the Malz method assumes that it is quadratic, the Vanna-Volga method allows for a more general shape, based on construction of locally replicating portfolios. Table 9 shows that estimates of our baseline regressions using moments computed from the Vanna-Volga method are qualitatively identical to ones previously obtained using moments from the Malz method.

\section{[Insert Table 9 about here]}

Along the same lines, we re-estimate the baseline regressions using as dependent variables the implied volatility prices of at-the-money, 25-delta risk-reversal, and 25-delta butterfly currency options. Carr and $\mathrm{Wu}$ (2005) show that, under certain assumptions, the implied volatility of the at-the-money straddle and the ratios of the implied volatilities of the riskreversal and butterfly relative to the at-the-money straddle can be linked directly to the second, third, and fourth moments of the risk-neutral density of expected changes of the underlying asset.

\section{[Insert Table 10 about here]}

Table 10 reports the estimation output. We can see that the estimated coefficients associated with policy changes that tighten controls on nonresidents are generallly negative. However, the size of the effects on the 25-delta butterfly tends to be smaller than the size of the effect on at-the-money straddle. This implies that the ratio of the implied volatility price of

the butterfly relative to the at-the-money straddle is increasing, which, according to Carr and $\mathrm{Wu}(2005)$, is associated with an increase in kurtosis. Table 10 also shows that a one-unit policy easing of capital controls on residents significantly reduces the prices of the at-the-money straddle, the 25 delta risk-reversal, and the 25-delta butterfly. However, the magnitude of the effect on the prices of the risk-reversal and butterfly are larger, which helps us understand the reduction in skewness and kurtosis described by our baseline regressions. With respect to the 
tightening of prudential FX measures not specific to FX derivatives, Table 10 reviews that the coefficients associated with the implied volatility of at-the-money straddle are not statistically significant with magnitudes very close to zero. Additionally, the coefficients associated with the 25-delta risk-reversal and 25-delta butterfly are negative and larger in size, which explains the reduction in skewness and kurtosis captured by the baseline regressions.

\subsection{Collapsing into Quarterly Data}

Our final robustness check revisits the "over-rejection of the null hypothesis" problem in difference-in-differences estimations. In our methodological section, we mentioned how Bertrand et al. (2004) document a severe bias in standard errors when the independent variable of interest is serially correlated, leading difference-in-differences estimators to over-reject the null hypothesis of no treatment effect in randomly generated placebo laws. Bertrand et al. (2004) also show that varying the number of cross section observations does not change the extent of over-rejection, but reducing the number of time periods helps significantly. Thus, we collapse our daily data into quarterly frequency, that is, we reduce the time series dimension from 505 to eight periods. Then, we re-estimate our baseline regressions with a panel of 25 currencies/countries and eight quarters, still computing standard errors that account for two dimensions of within-cluster correlation (country and time). Once again, the results reported in Table 11 are qualitatively the same as the ones obtained from our baseline regressions with daily data.

\section{[Insert Table 11 about here]}

\section{Conclusion}

In this paper we assess whether the recent wave of capital controls and prudential FX measures helped effectively deliver exchange rate stability. Particularly, we calculate differencein-differences estimators of the effect of policy changes in capital controls and prudential FX measures on different aspects of exchange rate stability implied by currency options - volatility, absolute crash risk, and tail risk-between July 1, 2009, and June 30, 2011. We find empirical 
evidence that tightening controls on nonresidents creates an illusive stability gain: It suppresses daily exchange rate fluctuations at a cost of increasing the probability of currency crisis and with no clear benefits to absolute crash risk. However, easing controls on residents truly improves exchange rate stability across all dimensions: The distribution of future expected exchange rate changes becomes less volatile and more symmetric, and with "thinner" tails. Our estimates also suggest that the tightening of prudential FX measures that are not specific to derivative markets significantly reduces absolute crash risk and tail risk, with no effect on volatility.

\section{References}

[1] Angrist, J., Pischke, J., 2008. Mostly harmless econometrics: An empiricist's companion. Princeton, NJ: Princeton University Press.

[2] Bakshi, G., Kapadia, N., Madan, D., 2003. Stock return characteristics, skew laws and the differential pricing of individual equity options. Review of Financial Studies 16, 101-143.

[3] Bertrand, M., Duflo, E., Mullainathan, S., 2004. How much should we trust differencein-differences estimates? Quarterly Journal of Economics 119, 249-275.

[4] Binici, M., Hutchison, M., Schindler, M., 2011. Controlling capital? Legal restrictions and the asset composition of international financial flows. Journal of International Money and Finance 29, 666-684.

[5] Breeden, D., Litzenberger, R., 1978. Prices of state-contingent claims implicit in option prices. Journal of Business 51, 621-651.

[6] Brunnermeier, M., Nagel, S., Pedersen, L., 2008. Carry trades and currency crashes. NBER Macroeconomics Annual 23, 313-347.

[7] Carr, P., Wu, L., 2005. The information content of straddles, risk reversals and butterfly spreads. Manuscript.

[8] Castagna, A., Mercurio, F., 2007. The Vanna-Volga method for implied volatilities. Risk, 106-111.

[9] Chernov, M., Graveline, J., Zviadadze, I., 2012. Crash risk in currency returns. Manuscript.

[10] Chinn, M., Ito, H., 2006. What matters for financial development? Capital controls, institutions, and interactions. Journal of Development Economics 81, 163-192.

[11] Chinn, M., Ito, H., 2008. A new measure of financial openness. Journal of Comparative Policy Analysis 10, 309-322. 
[12] Dooley, M., 1997. A survey of the literature on controls over international capital transactions. IMF Staff Papers 43, 639-687.

[13] Edison, H., Warnock, F., 2003. A simple measure of the intensity of capital controls. Journal of Empirical Finance 10, 81-103.

[14] Eichengreen, B., 2001. Capital account liberalization: What do cross-country studies tell us? The World Bank Economic Review 15, 341-365.

[15] Engel, C., Hakkio, C., 1993. Exchange rate regimes and volatility. Economic Review QIII, $43-58$.

[16] Engel, C., Hakkio, C., 1996. The distribution of exchange rates in the EMS. International Journal of Finance and Economics 1, 55-67.

[17] Glick, R., Guo, X., Hutchison, M., 2006. Currency crisis, capital-account liberalization, and selection bias. Review of Economics and Statistics 88, 698-714.

[18] Glick, R., Hutchison, M., 2005. Capital controls and exchange rate instability in developing economies. Journal of International Money and Finance 24, 387-412.

[19] Habermeier, K., Kokenyne, A., Baba, C., 2011. The effectiveness of capital controls and prudential policies in managing large inflows. IMF Staff Discussion Note 11/14.

[20] Jurek, J., 2007. Crash-neutral currency carry trades. Manuscript.

[21] Lane, P., Milesi-Ferretti, G., 2007. The external wealth of nations mark II: Revised and extended estimates of foreign assets and liabilities, 1970-2004. Journal of International Economics 73, 223-50.

[22] Lipton, A., McGhee, W., 2002. Universal Barriers. Risk, 81-85.

[23] Malz, A., 1997. Estimating the probability distribution of the future exchange rate from option prices. Journal of Derivatives 5, 18-36.

[24] Ostry, J., Ghosh, A., Habermeier, K., Chamon, M., Qureshi, M., Reinhardt, D., 2010. Capital inflows: The role of controls. IMF Staff Position Note 10/04.

[25] Ostry, J., Ghosh, A., Habermeier, K., Laeven, L., Chamon, M., Qureshi, M., Kokenyne, A., 2011. Managing capital inflows: What tools to use? IMF Staff Discussion Note 11/06.

[26] Petersen, M., 2009. Estimating standard errors in finance panel data sets: Comparing approaches. Review of Financial Studies 22, 435-480.

[27] Quinn, D., 1997. The correlates of change in international financial regulation. American Political Science Review 91, 531-551.

[28] Quinn, D., Toyoda, A., 2008. Does capital account liberalization lead to growth? Review of Financial Studies 21, 1403-1449.

[29] Qureshi, M., Ostry, J., Ghosh, A., Chamon, M., 2011. Managing capital inflows: The role of capital controls and prudential policies. NBER Working Paper No. 17363. 
[30] Schindler, M., 2009. Measuring financial integration: A new data set. IMF Staff Papers 56, 222-238.

[31] Taleb, N., Blyth, M., 2011. The Black Swan of Cairo. Foreign Affairs 90, 33-39. 
Figure 1: Options-implied probability density functions for the CAD/USD 3, 6, and 12 months ahead, using prices on March 1, 2010

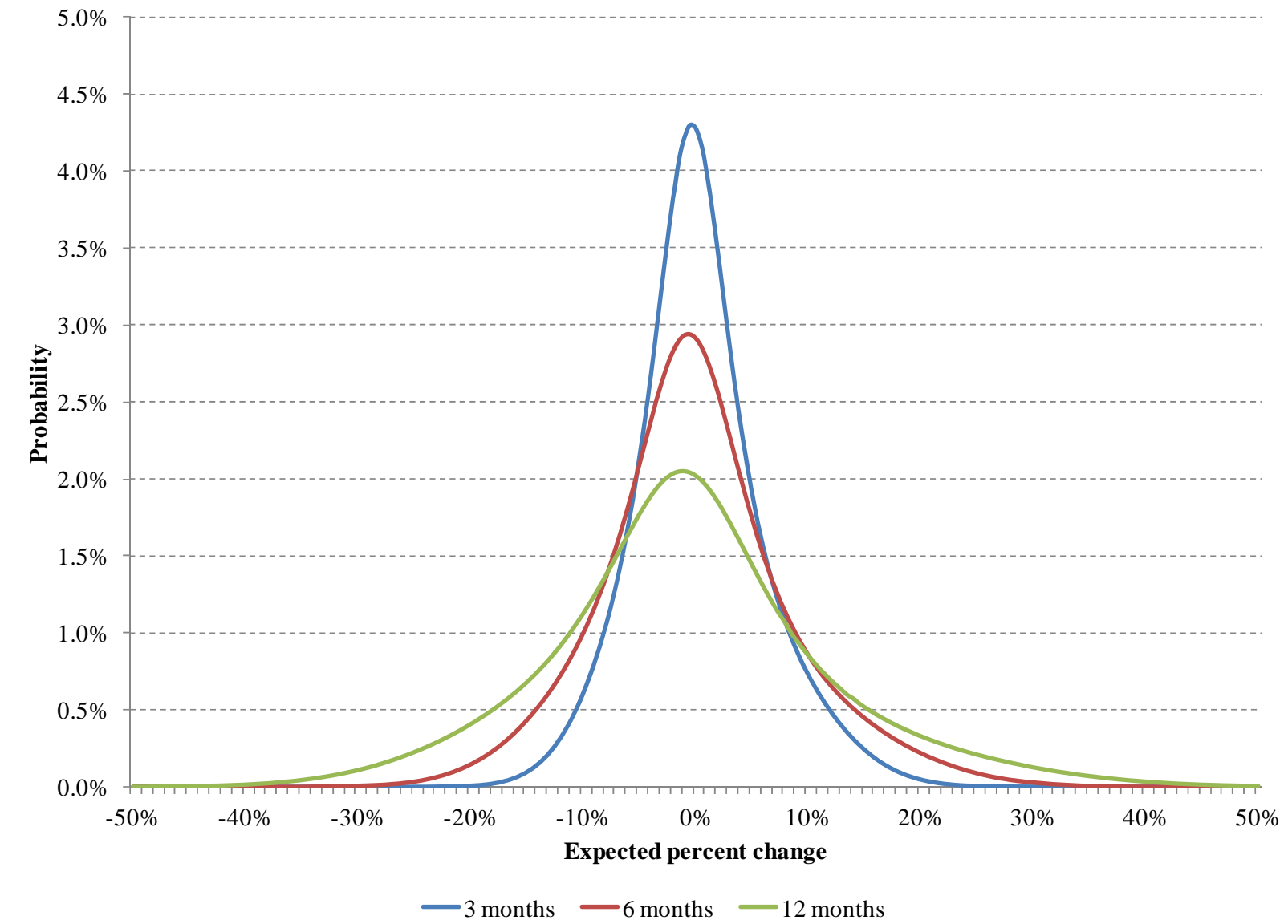

Source: Risk-neutral densities extracted from 3-, 6-, and 12-month currency options using the Malz method. CAD quoted against the USD, that is, a positive expected percent change implies that the CAD is expected to depreciate against the USD. 
Figure 2: Options-implied probability density functions for the CAD/USD 3 Months Ahead, using prices on March 1, 2010, March 17, 2010, and June 7, 2010

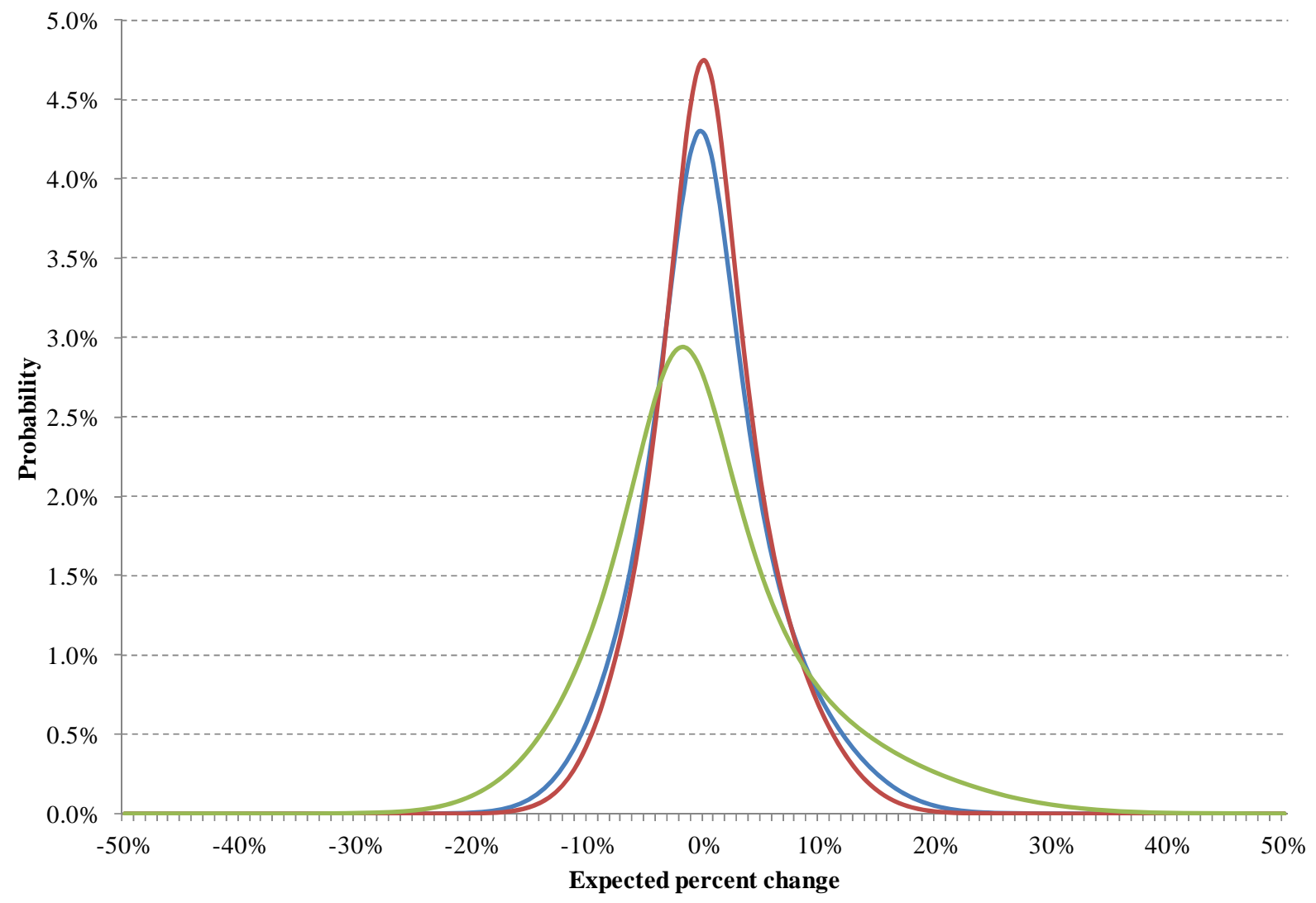

— March 1, 2010 - March 19, 2010 - May 20, 2010

Source: Risk-neutral densities extracted from 3-month currency options using the Malz method. CAD quoted against the USD, that is, a positive expected percent change implies that the CAD is expected to depreciate against the USD. 
Figure 3: Options-implied probability density functions for the CAD, RUB, INR, BRL, ZAR, and AUD all quoted against the USD 3 months ahead, using prices on March 1, 2010

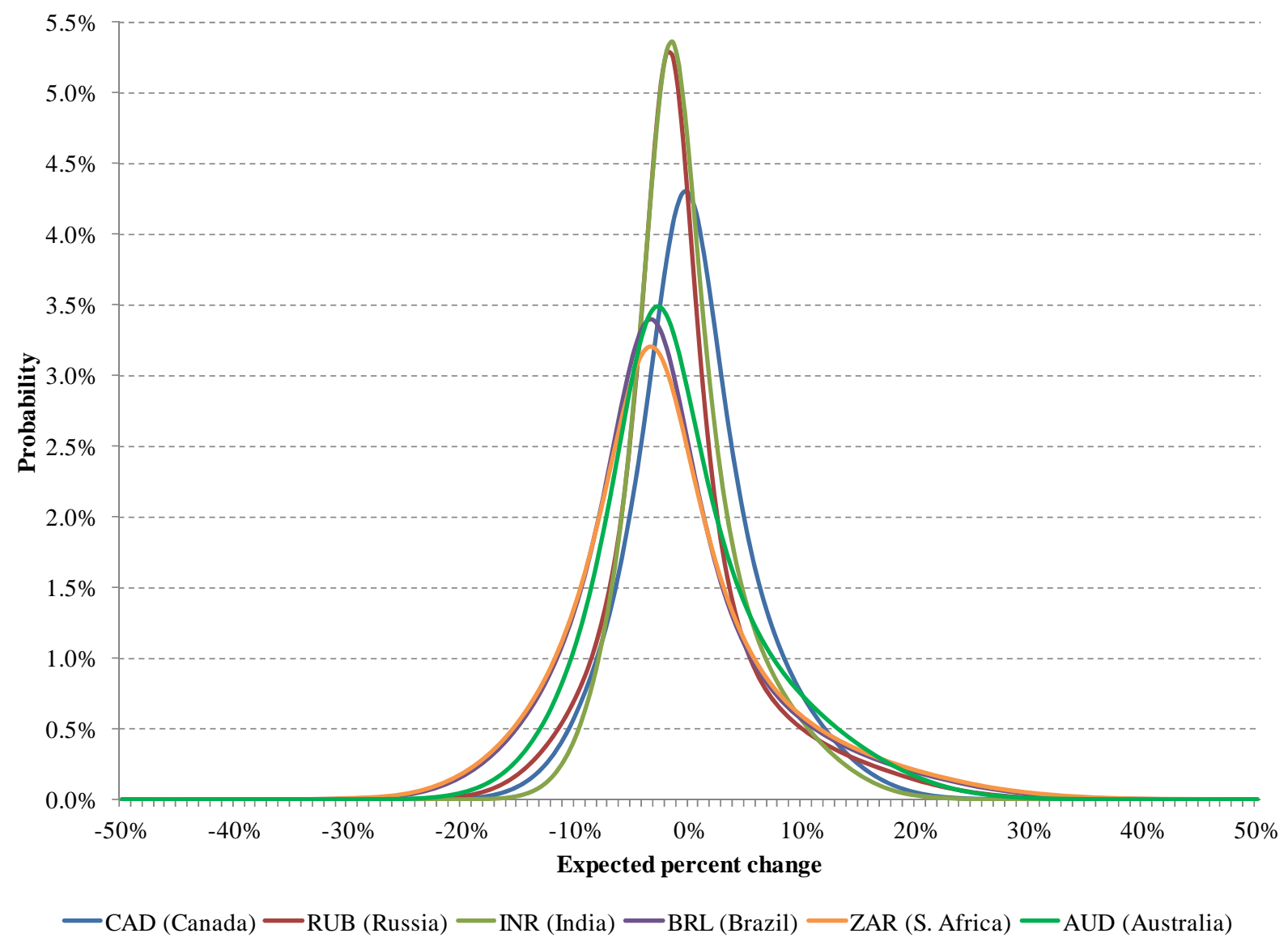

Source: Risk-neutral densities extracted from 3-month currency options using the Malz method. All currencies are quoted against the USD, that is, a positive expected percent change implies that the currency is expected to depreciate against the USD. 
Figure 4: Monthly Number of Policy Changes in Capital Controls on Inflows and Outflows and Google SVI for Search Query "Quantitative Easing”

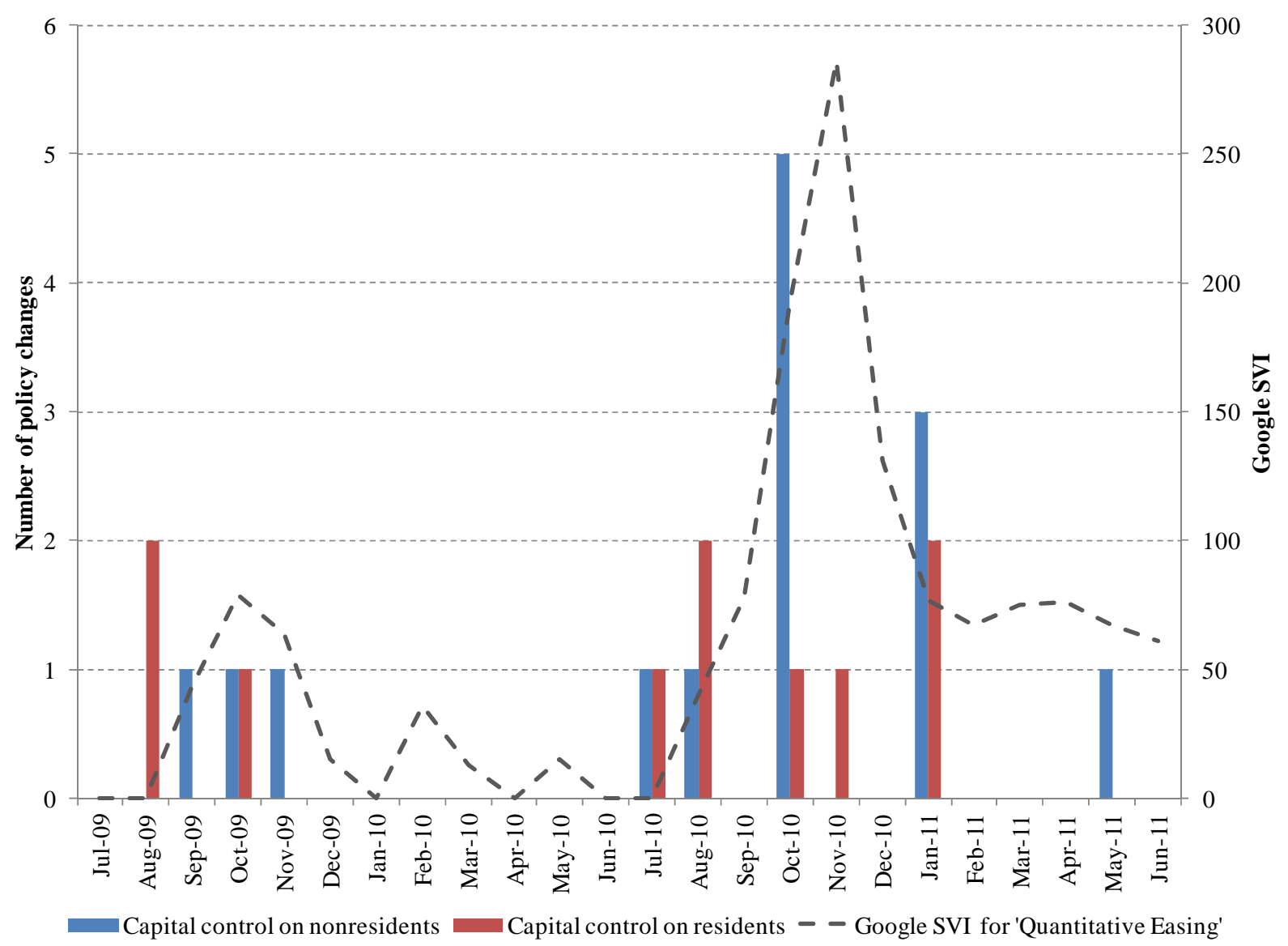

Source: IMF’s AREAER, Google, and authors' calculations. 
Figure 5: Monthly Number of Policy Changes in Prudential Measures on FX Derivatives and Other FX Assets and Liabilities and Google SVI for Search Query "Quantitative Easing”

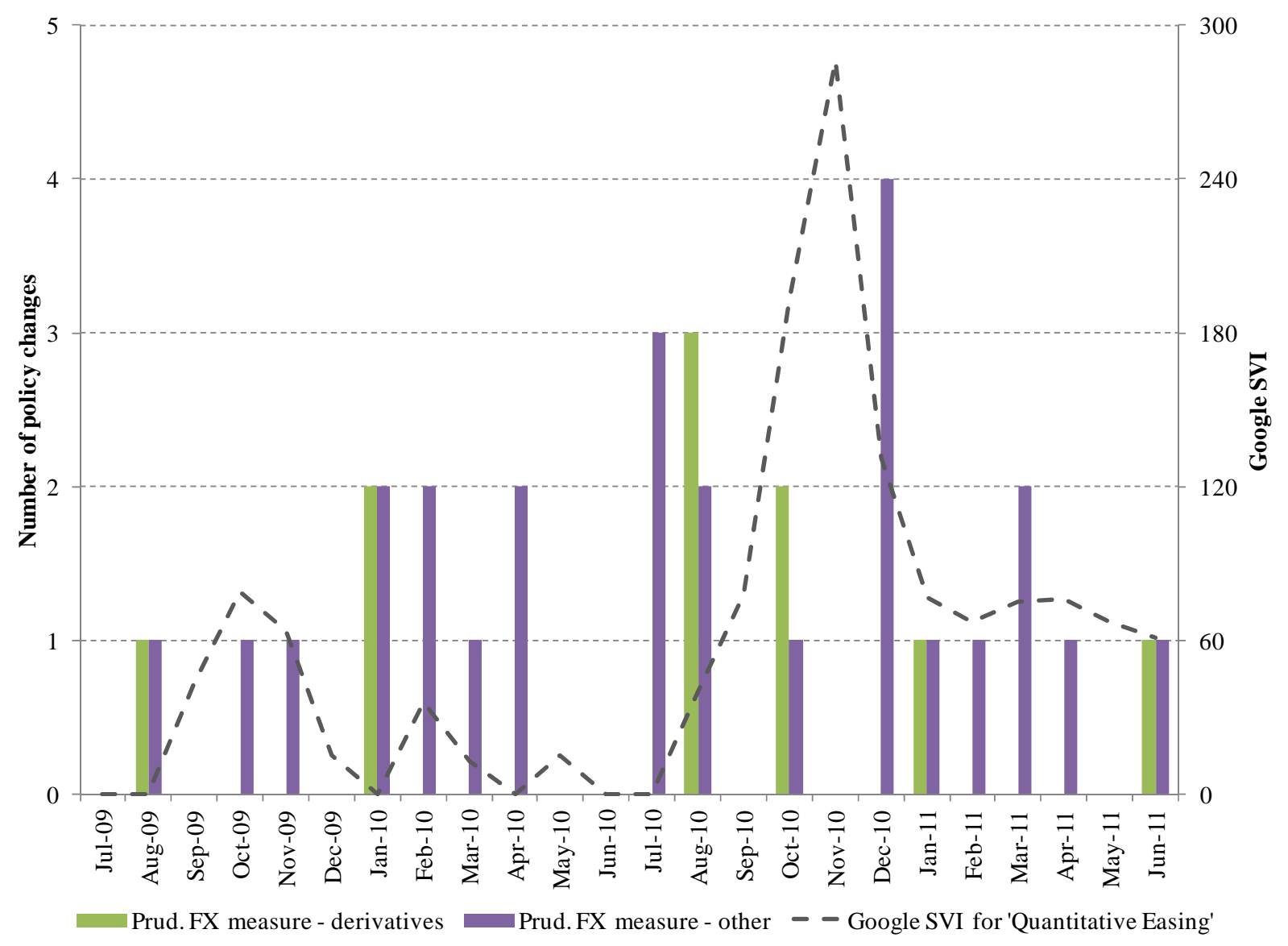

Source: IMF’s AREAER, Google, and authors' calculations. 
Figure 6: Monthly Evolution of Implied Volatility for Control and Treatment Groups
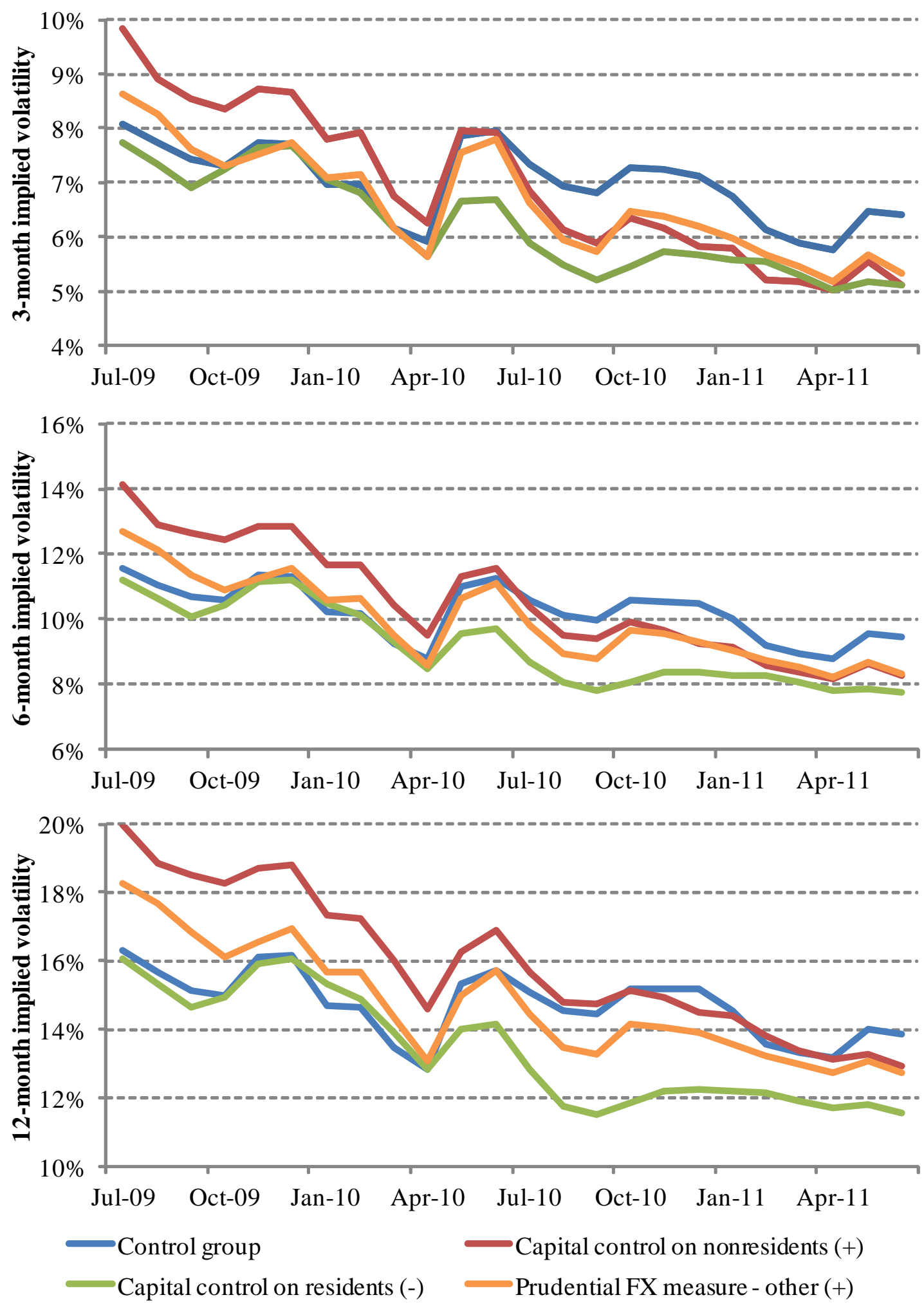

Source: Monthly averages of natural logs of daily volatility data from July 1, 2009, and June 30, 2011. Volatility is calculated as the second moment (standard deviation) of risk-neutral densities extracted from currency options using the Malz method. The symbols “+” and "-" denote that treatment group includes only countries that on average have tightened and eased, respectively, capital controls or prudential FX measures. 
Figure 7: Monthly Evolution of Implied Absolute Crash Risk for Control and Treatment Groups
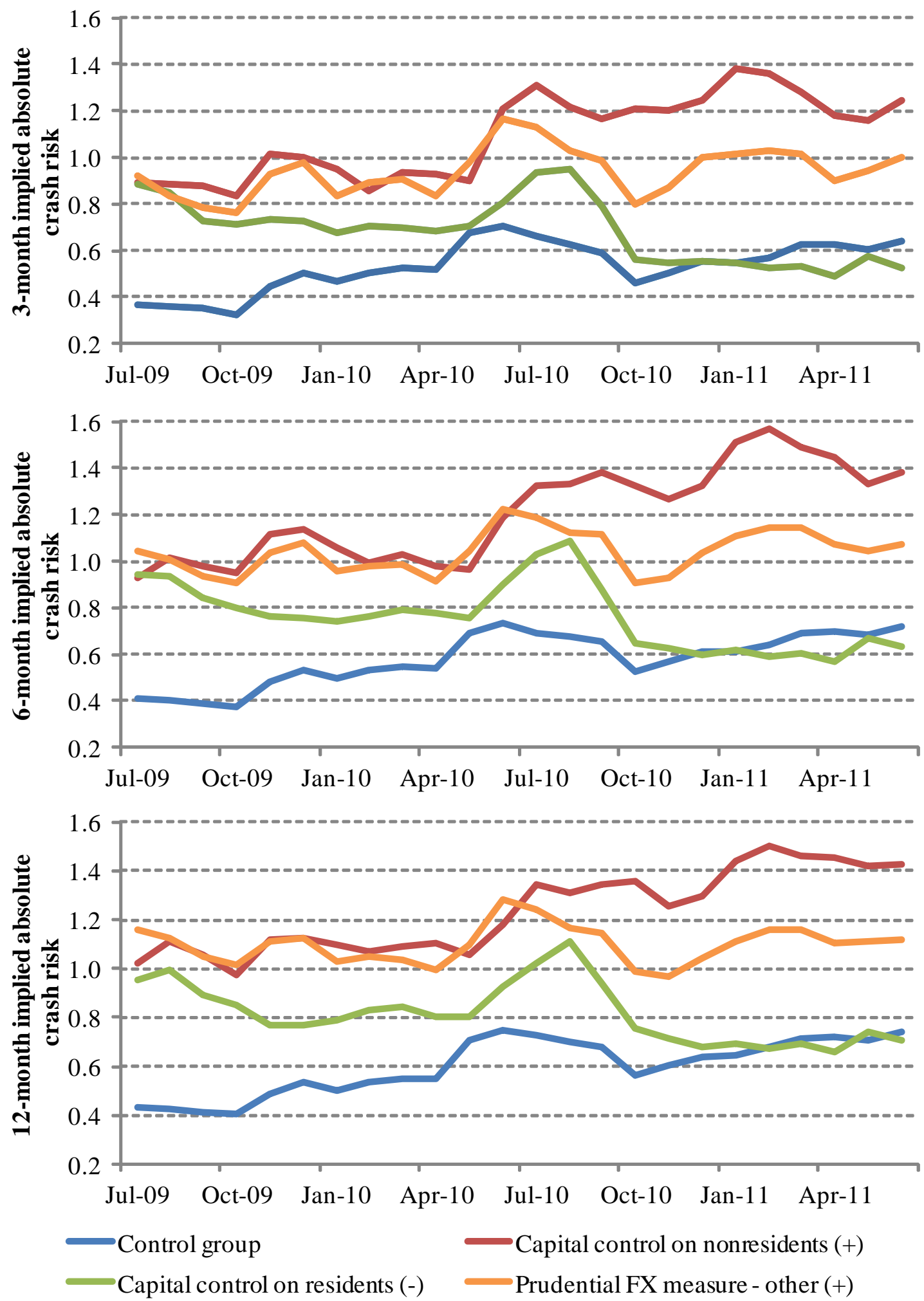

Source: Monthly averages of natural logs of daily tail risk data from July 1, 2009, and June 30, 2011. Absolute crash risk is calculated as the absolute value of the third moment (skewness) of risk-neutral densities extracted from currency options using the Malz method. The symbols “+” and "-” denote that treatment group includes only countries that on average have tightened and eased, respectively, capital controls or prudential FX measures. 
Figure 8: Monthly Evolution of Implied Tail Risk for Control and Treatment Groups
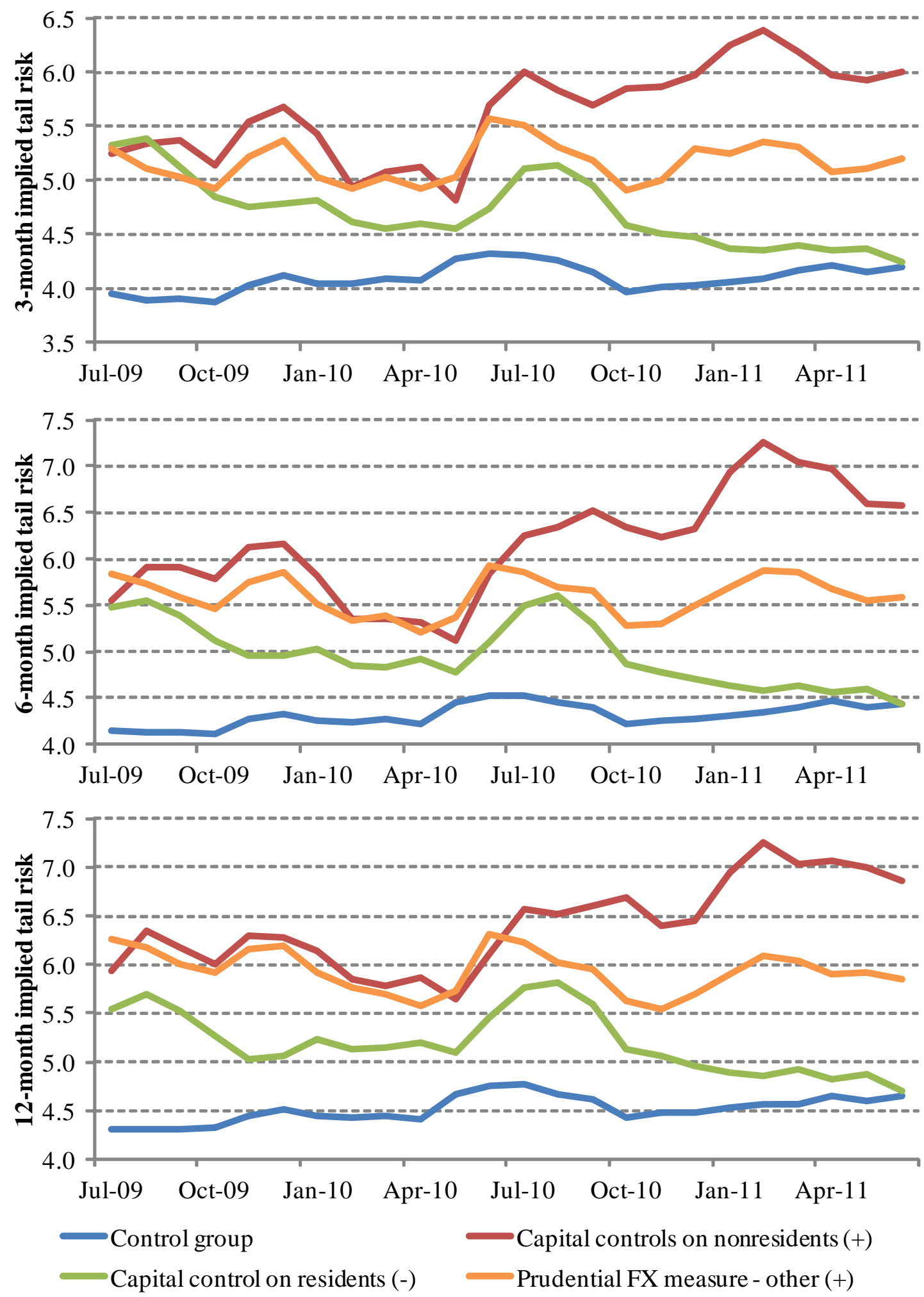

Source: Monthly averages of natural logs of daily tail risk data from July $1^{\text {st }}, 2009$ and June 30, 2011. Tail risk is calculated as the fourth moment (kurtosis) of risk-neutral densities extracted from currency options using the Malz method. The symbols “+” and “-” denote that treatment group includes only countries that on average have tightened and eased, respectively, capital controls or prudential FX measures. 
Table 1: Summary Statistics for 3-Month Currency Options-Implied Volatility, Crash Risk, and Tail Risk

\begin{tabular}{|c|c|c|c|c|c|c|c|c|c|c|c|c|c|c|}
\hline \multirow{2}{*}{\multicolumn{2}{|c|}{$\begin{array}{l}\text { Country Name / } \\
\text { Currency Code }\end{array}$}} & \multirow{3}{*}{$\frac{\text { Obs. }}{505}$} & \multicolumn{4}{|c|}{ Volatility (Stand. Deviation) } & \multicolumn{4}{|c|}{ Crash Risk (Skewness) } & \multicolumn{4}{|c|}{ Tail Risk (Kurtosis) } \\
\hline & & & \multirow{2}{*}{$\frac{\text { Mean }}{7.7 \%}$} & \multirow{2}{*}{$\begin{array}{l}\text { S.D. } \\
1.0 \%\end{array}$} & \multirow{2}{*}{$\frac{\text { Min. }}{5.8 \%}$} & \multirow{2}{*}{$\frac{\text { Max. }}{11.4 \%}$} & \multirow{2}{*}{$\frac{\text { Mean }}{0.7}$} & \multirow{2}{*}{$\frac{\text { S.D. }}{0.2}$} & \multirow{2}{*}{$\frac{\text { Min. }}{0.3}$} & \multirow{2}{*}{$\begin{array}{c}\text { Max. } \\
1.1\end{array}$} & \multirow{2}{*}{$\frac{\text { Mean }}{4.1}$} & \multirow{2}{*}{$\frac{\text { S.D. }}{0.3}$} & \multirow{2}{*}{$\frac{\text { Min. }}{3.6}$} & \multirow{2}{*}{$\frac{\text { Max }}{4.9}$} \\
\hline Australia & $A U D$ & & & & & & & & & & & & & \\
\hline $\mathrm{Braz}$ & $B R L$ & 491 & $7.9 \%$ & $1.4 \%$ & $5.5 \%$ & $10.7 \%$ & 1.1 & 0.2 & 0.7 & 1. & 5.3 & 0.4 & 4.5 & 6.2 \\
\hline Canada & $C A D$ & 504 & $6.2 \%$ & $1.1 \%$ & $4.2 \%$ & $9.0 \%$ & 0.3 & 0.2 & -0.1 & 0.8 & 3.8 & 0.2 & 3.4 & 4.3 \\
\hline China & $C N Y$ & 489 & $1.5 \%$ & $0.5 \%$ & $0.8 \%$ & $2.8 \%$ & -0.7 & 0.7 & -2.7 & 0.5 & 6.2 & 2.4 & 3.4 & 12.6 \\
\hline Colombia & COP & 494 & $8.0 \%$ & $1.6 \%$ & $6.0 \%$ & $11.0 \%$ & 0.8 & 0.2 & 0.5 & 1.5 & 5.0 & 0.4 & 4.4 & 6.1 \\
\hline Czech $R e$ & $C Z K$ & 497 & $7.5 \%$ & $0.6 \%$ & $6.2 \%$ & $9.0 \%$ & 0.5 & 0.2 & 0.2 & 0.8 & 4.1 & 0.2 & 3.7 & 4.7 \\
\hline Denm & $D K K$ & 464 & $6.5 \%$ & $0.6 \%$ & $5.4 \%$ & $8.5 \%$ & 0. & 0.2 & -0.2 & 0. & 3.7 & 0.2 & 3.4 & 4.5 \\
\hline Hung & HUF & 503 & $9.4 \%$ & $1.1 \%$ & $6.8 \%$ & $11.9 \%$ & 0.1 & 0.1 & 0.5 & 0.5 & 4.3 & 0.1 & 4.0 & 4.8 \\
\hline di & II & 47 & $5.3 \%$ & $0.8 \%$ & $3.8 \%$ & $8.7 \%$ & 0.7 & 0.2 & 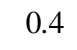 & 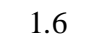 & 4.4 & 0.4 & 3.8 & 7.2 \\
\hline Indonesic & $I D R$ & 500 & $6.0 \%$ & $1.6 \%$ & $3.8 \%$ & $10.4 \%$ & 1 & 0.2 & 0.5 & 1. & 6.0 & 0.6 & 4.1 & 8.5 \\
\hline Israel & ILS & 501 & $4.7 \%$ & $0.8 \%$ & $3.4 \%$ & $7.5 \%$ & 0.3 & 0.2 & -0.1 & 0.7 & 4.4 & 0.2 & 3.9 & 5.1 \\
\hline Malaysia & $M Y R$ & 492 & $4.4 \%$ & $0.6 \%$ & $3.5 \%$ & $6.8 \%$ & 0.7 & 0.2 & 0.2 & 1.2 & 4.5 & 0.3 & 4.1 & 5.7 \\
\hline Mexi & $M X N$ & 505 & $6.9 \%$ & $1.1 \%$ & $5.0 \%$ & $9.3 \%$ & 1.0 & 0.1 & 0.4 & 1.2 & 5.1 & 0.2 & 4.4 & 5.7 \\
\hline New 2 & $N Z D$ & 5 & $8.1 \%$ & $1.1 \%$ & $6.3 \%$ & $11.8 \%$ & 0.7 & 0.1 & 0.3 & 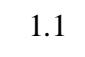 & 4.1 & 0.3 & 0 & 4.8 \\
\hline Norw & NOK & 5 & $7.6 \%$ & $0.7 \%$ & $5.8 \%$ & $9.1 \%$ & & 0.1 & & & & 0.1 & 3.4 & 4.2 \\
\hline Philippines & PHP & 494 & $4.9 \%$ & $0.7 \%$ & $3.6 \%$ & $7.2 \%$ & . & 0.2 & 0.4 & 1. & 4.9 & 0.8 & 3.9 & 7.4 \\
\hline Poland & $P L N$ & 505 & $9.3 \%$ & $1.0 \%$ & $7.1 \%$ & $11.6 \%$ & 0.6 & 0.1 & 0.3 & 0.8 & 4.2 & 0.2 & 3.8 & 4.9 \\
\hline Russia & $R U B$ & 500 & $6.6 \%$ & $1.4 \%$ & $4.4 \%$ & $9.8 \%$ & 1.0 & 0.2 & 0.4 & 1.4 & 5.3 & 0.5 & 4.5 & 6.7 \\
\hline Singapore & $S G D$ & 485 & $3.6 \%$ & $0.4 \%$ & $2.7 \%$ & $5.4 \%$ & 0.5 & 0.2 & 0.0 & 1.0 & 4.2 & 0.2 & 3.7 & 4.9 \\
\hline South Africa & ZAR & 502 & $8.7 \%$ & $1.2 \%$ & $7.2 \%$ & $11.5 \%$ & 0.0 & 0.1 & 0.4 & 1. & 4.1 & 0.2 & 4.2 & 5.3 \\
\hline South Korea & $K R W$ & 501 & $7.3 \%$ & $1.1 \%$ & $5.3 \%$ & $13.9 \%$ & or & 0.2 & 0.4 & 1.6 & 5.1 & 0.4 & 4.2 & 6.6 \\
\hline Sweden & SEK & 504 & $7.8 \%$ & $0.9 \%$ & $6.0 \%$ & $10.0 \%$ & 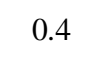 & 0.2 & 0.0 & .0. & J. & 0.2 & 3.1 & 4.2 \\
\hline Switzerland & $\mathrm{CHF}$ & 502 & $6.1 \%$ & $0.4 \%$ & $5.0 \%$ & $7.5 \%$ & 0 & 0.2 & -0.3 & 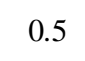 & 3.6 & 0.1 & 3.4 & 4.0 \\
\hline Thailand & THB & 488 & $3.2 \%$ & $0.5 \%$ & $2.5 \%$ & $5.3 \%$ & 0.4 & 0.3 & 0.0 & 1.1 & 4.3 & 0.4 & 3.7 & 5.5 \\
\hline Turkey & $T R Y$ & 505 & $6.8 \%$ & $0.7 \%$ & $5.6 \%$ & $9.0 \%$ & 0.9 & 0.2 & 0.4 & 1.2 & 4.9 & 0.3 & 4.3 & 6.0 \\
\hline \multicolumn{2}{|c|}{ All countries } & 3,924 & $6.5 \%$ & $2.0 \%$ & $0.8 \%$ & $13.9 \%$ & 0.5 & 0.5 & -2.7 & 1.9 & 4.5 & 0.9 & 3.1 & 12.6 \\
\hline
\end{tabular}

Source: Summary statistics of daily data from July 1, 2009, and June 30, 2011. Implied volatility, crash risk, and tail risk are calculated as the standard deviation, skewness, and kurtosis, respectively, of risk-neutral densities extracted from 3-month currency options using the Malz method. All currencies are quoted against the USD. 
Table 2: Summary Statistics for 6-Month Currency Options-Implied Volatility, Crash Risk, and Tail Risk

\begin{tabular}{|c|c|c|c|c|c|c|c|c|c|c|c|c|c|c|}
\hline \multirow{2}{*}{\multicolumn{2}{|c|}{$\begin{array}{l}\text { Country Name / } \\
\text { Currency Code }\end{array}$}} & \multirow{3}{*}{$\frac{\text { Obs. }}{505}$} & \multicolumn{4}{|c|}{ Volatility (Stand. Deviation) } & \multicolumn{4}{|c|}{ Crash Risk (Skewness) } & \multicolumn{4}{|c|}{ Tail Risk (Kurtosis) } \\
\hline & & & Mean & S.D. & Min. & Max. & Mean & S.D. & Min. & Max. & Mean & S.D. & Min. & Max. \\
\hline Australia & $A U D$ & & $11.4 \%$ & $1.2 \%$ & $8.9 \%$ & $15.5 \%$ & 0.8 & 0.2 & 0.4 & 1.1 & 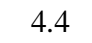 & 0.3 & 3.7 & 5.1 \\
\hline Braz & $B R L$ & 490 & $11.6 \%$ & $1.7 \%$ & $8.7 \%$ & $14.8 \%$ & 1.2 & 0.2 & 0.8 & 1.5 & 5.6 & 0.4 & 4.7 & 6.5 \\
\hline Canada & $C A D$ & 505 & $9.1 \%$ & $1.5 \%$ & $6.5 \%$ & $12.4 \%$ & 0.3 & 0.2 & -0.1 & 0.8 & 3.9 & 0.2 & 3.6 & 4.5 \\
\hline China & $C N Y$ & 474 & $2.6 \%$ & $0.5 \%$ & $1.9 \%$ & $4.0 \%$ & -0.5 & 0.6 & -2.1 & 0.4 & 5.3 & 1.5 & 3.4 & 9.7 \\
\hline Colombia & COP & 492 & $11.6 \%$ & $2.0 \%$ & $9.2 \%$ & $15.4 \%$ & 0.9 & 0.2 & 0.6 & 1.5 & 5.3 & 0.4 & 4.8 & 6.7 \\
\hline Czech Republic & $C Z K$ & 500 & $10.7 \%$ & $0.7 \%$ & $9.2 \%$ & $12.4 \%$ & 0.5 & 0.1 & 0.2 & 0.8 & 4.3 & 0.2 & 3.8 & 4.8 \\
\hline Denm & $D K K$ & 466 & $9.6 \%$ & $0.7 \%$ & $8.2 \%$ & $11.8 \%$ & 0.3 & 0.2 & -0.2 & 0. & 3.9 & 0.2 & 3.4 & 4.7 \\
\hline Hung & HUF & 502 & $13.6 \%$ & $1.4 \%$ & $10.8 \%$ & $16.2 \%$ & 0.7 & 0.1 & 0.5 & 0.9 & 4.5 & 0.2 & 4.3 & 5.0 \\
\hline$n d i$ & $I N R$ & 473 & $7.9 \%$ & $1.1 \%$ & $6.2 \%$ & $11.5 \%$ & 0.8 & 0.2 & .5 & 1.7 & 4.8 & 0.5 & 4.1 & 7.3 \\
\hline Indonesia & $I D R$ & 500 & $9.6 \%$ & $1.9 \%$ & $6.7 \%$ & $15.0 \%$ & 1.3 & 0.2 & 0.7 & 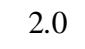 & 6.7 & 0.8 & 4.7 & 9.1 \\
\hline Israel & ILS & 503 & $6.7 \%$ & $1.0 \%$ & $5.1 \%$ & $10.1 \%$ & 0.3 & 0.2 & -0.1 & 0.7 & 4.6 & 0.2 & 4.0 & 5.2 \\
\hline Malaysia & $M Y R$ & 492 & $6.7 \%$ & $0.7 \%$ & $5.5 \%$ & $9.2 \%$ & 0.8 & 0.2 & 0.3 & 1.2 & 5.1 & 0.4 & 4.4 & 5.8 \\
\hline Mexico & $M X N$ & 504 & $10.1 \%$ & $1.3 \%$ & $8.0 \%$ & $13.1 \%$ & 1.1 & 0.1 & 0.5 & 1.4 & 5.5 & 0.3 & 4.5 & 6.4 \\
\hline New Zealan & $N Z D$ & 505 & $12.1 \%$ & $1.4 \%$ & $9.8 \%$ & $16.3 \%$ & 0.7 & 0.1 & 0.4 & 1.1 & 4.3 & 0.3 & 3.7 & 5.0 \\
\hline 列 & NOK & 496 & $11.0 \%$ & $0.9 \%$ & $8.9 \%$ & $13.0 \%$ & 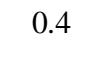 & 0.2 & 0.0 & 0 & 5. & . & 3.5 & 1.0 \\
\hline Philippines & PHP & 500 & $7.4 \%$ & $1.0 \%$ & $5.8 \%$ & $10.1 \%$ & & 0.2 & 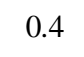 & & . & 0.8 & 4.3 & 7.8 \\
\hline Poland & $P L N$ & 505 & $13.4 \%$ & $1.2 \%$ & $11.0 \%$ & $16.0 \%$ & 0.7 & 0.1 & 0.4 & 0. & 4.4 & 0.2 & 4.0 & 5.0 \\
\hline Russia & $R U B$ & 499 & $10.0 \%$ & $1.9 \%$ & $7.2 \%$ & $14.3 \%$ & 1.1 & 0.2 & 0.4 & 1.5 & 5.8 & 0.6 & 4.7 & 7.4 \\
\hline Singapore & $S G D$ & 501 & $5.4 \%$ & $0.5 \%$ & $4.0 \%$ & $7.5 \%$ & 0.6 & 0.2 & 0.0 & 1.1 & 4.6 & 0.3 & 3.9 & 5.4 \\
\hline South Africa & $\mathrm{ZAR}$ & 505 & $12.5 \%$ & $1.6 \%$ & $10.7 \%$ & $16.0 \%$ & 0.9 & 0.1 & 0.5 & 1.1 & 5.0 & 0.2 & 4.4 & 5.5 \\
\hline South Korea & $K R W$ & 504 & $10.6 \%$ & $1.3 \%$ & $7.9 \%$ & $17.7 \%$ & 1.0 & 0.2 & 0.4 & 1.7 & 5.5 & 0.4 & 4.4 & 7.2 \\
\hline Sweden & SEK & 49 & $11.2 \%$ & $1.1 \%$ & $9.0 \%$ & $13.7 \%$ & 0.4 & 0.2 & 0.0 & 0 . & 3.8 & 0.2 & 3.1 & 4.3 \\
\hline Switzerland & CHF & 505 & $8.9 \%$ & $0.6 \%$ & $7.5 \%$ & $10.6 \%$ & -0.1 & 0.2 & -0.3 & 0.5 & 3.8 & 0.1 & 3.5 & 4.2 \\
\hline Thailand & THB & 493 & $5.1 \%$ & $0.7 \%$ & $3.8 \%$ & $8.3 \%$ & 4 & 0.3 & 0.0 & 1.2 & 4.3 & 0.4 & 3.4 & 6.2 \\
\hline Turkey & $T R Y$ & 505 & $10.2 \%$ & $0.9 \%$ & $8.7 \%$ & $12.6 \%$ & 1.0 & 0.1 & 0.6 & 1.3 & 5.3 & 0.4 & 4.7 & 6.5 \\
\hline \multicolumn{2}{|l|}{ All countries } & 13,934 & $9.6 \%$ & $2.8 \%$ & $1.9 \%$ & $17.7 \%$ & 0.6 & 0.5 & -2.1 & 2.0 & 4.7 & 0.9 & 3.1 & 9.7 \\
\hline
\end{tabular}

Source: Summary statistics of daily data from July 1, 2009, and June 30, 2011. Implied volatility, crash risk, and tail risk are calculated as the standard deviation, skewness, and kurtosis, respectively, of risk-neutral densities extracted from 6-month currency options using the Malz method. All currencies are quoted against the USD. 
Table 3: Summary Statistics for 12-Month Currency Options-Implied Volatility, Crash Risk, and Tail Risk

\begin{tabular}{|c|c|c|c|c|c|c|c|c|c|c|c|c|c|c|}
\hline \multirow{2}{*}{\multicolumn{2}{|c|}{$\begin{array}{l}\text { Country Name / } \\
\text { Currency Code }\end{array}$}} & \multirow{3}{*}{$\begin{array}{c}\text { Obs. } \\
505\end{array}$} & \multicolumn{4}{|c|}{ Volatility (Stand. Deviation) } & \multicolumn{4}{|c|}{ Crash Risk (Skewness) } & \multicolumn{4}{|c|}{ Tail Risk (Kurtosis) } \\
\hline & & & \multirow{2}{*}{$\frac{\text { Mean }}{16.5 \%}$} & \multirow{2}{*}{$\frac{\text { S.D. }}{1.4 \%}$} & \multirow{2}{*}{$\frac{\text { Min. }}{13.2 \%}$} & \multirow{2}{*}{$\frac{\text { Max. }}{21.2 \%}$} & \multirow{2}{*}{$\frac{\text { Mean }}{0.8}$} & \multirow{2}{*}{$\frac{\text { S.D. }}{0.2}$} & \multirow{2}{*}{$\frac{\text { Min. }}{0.4}$} & \multirow{2}{*}{$\frac{\text { Max. }}{1.2}$} & \multirow{2}{*}{$\frac{\text { Mean }}{4.7}$} & \multirow{2}{*}{$\frac{\text { S.D. }}{0.4}$} & \multirow{2}{*}{$\frac{\text { Min. }}{3.8}$} & \multirow{2}{*}{$\frac{\text { Max }}{5.5}$} \\
\hline Australia & $A U D$ & & & & & & & & & & & & & \\
\hline $\mathrm{Braz}$ & $B R L$ & 491 & $17.2 \%$ & $1.9 \%$ & $13.9 \%$ & $20.8 \%$ & 1.1 & 0.2 & 0.8 & 1. & 5.5 & 0.4 & 4.8 & 6.3 \\
\hline Canada & $C A D$ & 505 & $13.1 \%$ & $1.9 \%$ & $9.6 \%$ & $17.2 \%$ & 0.3 & 0.2 & -0.1 & 0.7 & 4.0 & 0.2 & 3.7 & 4.7 \\
\hline China & $C N Y$ & 480 & $4.9 \%$ & $0.9 \%$ & $3.6 \%$ & $7.6 \%$ & -0.3 & 0.5 & -1.5 & 1.2 & 4.8 & 0.8 & 3.5 & 6.8 \\
\hline Colombia & COP & 491 & $16.9 \%$ & $2.4 \%$ & $14.0 \%$ & $21.2 \%$ & 0.9 & 0.2 & 0.6 & 1.4 & 5.6 & 0.5 & 4.9 & 6.9 \\
\hline Czech Republic & $C Z K$ & 497 & $15.2 \%$ & $0.7 \%$ & $13.1 \%$ & $17.0 \%$ & 0.6 & 0.1 & 0.3 & 0.7 & 4.4 & 0.2 & 4.0 & 4.9 \\
\hline Denm & $D K K$ & 465 & $14.0 \%$ & $0.9 \%$ & $12.2 \%$ & $16.3 \%$ & 0.4 & 0.3 & -0.2 & 0. & 4. & 0.2 & 3.6 & 4.8 \\
\hline Hung & HUF & 502 & $19.3 \%$ & $1.6 \%$ & $15.9 \%$ & $22.4 \%$ & 0.7 & 0.1 & 0.6 & 0.5 & 4.7 & 0.2 & 4.4 & 5.2 \\
\hline di & INR & 474 & $11.6 \%$ & $1.5 \%$ & $9.2 \%$ & $15.7 \%$ & 0.9 & 0.2 & 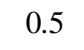 & 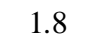 & 5.2 & 0.6 & 4.4 & 8.4 \\
\hline Indonesic & $I D R$ & 502 & $14.7 \%$ & $2.4 \%$ & $11.0 \%$ & $21.3 \%$ & 1.4 & 0.2 & 0.9 & 1. & 7.3 & 0.7 & 5.3 & 8.8 \\
\hline Israel & ILS & 504 & $9.4 \%$ & $1.3 \%$ & $7.6 \%$ & $13.5 \%$ & 0.3 & 0.2 & -0.1 & 0.7 & 4.7 & 0.2 & 4.1 & 5.4 \\
\hline Malaysia & $M Y R$ & 492 & $9.8 \%$ & $0.9 \%$ & $8.1 \%$ & $12.9 \%$ & 0.9 & 0.3 & 0.4 & 1.4 & 5.4 & 0.5 & 4.6 & 6.7 \\
\hline Mexi & $M X N$ & 500 & $14.6 \%$ & $1.5 \%$ & $12.2 \%$ & $18.2 \%$ & 1.0 & 0.1 & 0.5 & 1.3 & 5.6 & 0.3 & 4.7 & 6.2 \\
\hline New 2 & $N Z D$ & 50 & $17.6 \%$ & $1.7 \%$ & $14.6 \%$ & $22.8 \%$ & 0.8 & 0.1 & 0.5 & 1.2 & 4.5 & 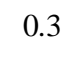 & $J$ & .4 \\
\hline Norw & NOK & 4 & $15.7 \%$ & $1.1 \%$ & $\%$ & $18.4 \%$ & & 0.2 & & & . & 0.1 & 3.6 & 4.5 \\
\hline Philippines & PHP & 499 & $11.0 \%$ & $1.3 \%$ & $9.0 \%$ & $14.4 \%$ & 1.0 & 0.2 & 0.6 & 1. & 5.7 & 0.7 & 4.7 & 8.1 \\
\hline Poland & $P L N$ & 500 & $18.9 \%$ & $1.3 \%$ & $16.3 \%$ & $22.0 \%$ & 0.7 & 0.1 & 0.4 & 0.8 & 4.7 & 0.2 & 4.2 & 5.3 \\
\hline Russia & $R U B$ & 499 & $14.9 \%$ & $2.8 \%$ & $11.3 \%$ & $21.9 \%$ & 1.1 & 0.2 & 0.4 & 1.4 & 6.2 & 0.6 & 5.1 & 7.3 \\
\hline Singapore & $S G D$ & 504 & $8.0 \%$ & $0.7 \%$ & $6.1 \%$ & $10.2 \%$ & 0.7 & 0.3 & 0.1 & 1.2 & 4.9 & 0.3 & 4.2 & 6.2 \\
\hline South Africa & ZAR & 505 & $17.8 \%$ & $2.0 \%$ & $15.5 \%$ & $21.9 \%$ & 0.9 & 0.1 & 0.5 & 1. & 0.2 & 0.2 & 4.6 & 5.7 \\
\hline South Korea & $K R W$ & 504 & $15.0 \%$ & $1.4 \%$ & $11.7 \%$ & $21.4 \%$ & 1.1 & 0.2 & 0.6 & 1.7 & 5.9 & 0. & 4.8 & 7.5 \\
\hline$S$ & SEK & 501 & $15.9 \%$ & $1.3 \%$ & $13.4 \%$ & $18.9 \%$ & 0.7 & 0.2 & 0.0 & .0. & 3.9 & 0.2 & 3.1 & 4.5 \\
\hline Switzerland & $\mathrm{CHF}$ & 505 & $12.8 \%$ & $0.8 \%$ & $10.9 \%$ & $15.1 \%$ & -0.1 & 0.2 & -0.4 & 0.4 & 3.9 & 0.1 & 3.6 & 4.4 \\
\hline Thailand & THB & 496 & $8.0 \%$ & $1.3 \%$ & $5.7 \%$ & $12.7 \%$ & 0.5 & 0.3 & 0.0 & 1.3 & 4.3 & 0.5 & 3.4 & 6.7 \\
\hline Turkey & $T R Y$ & 504 & $15.2 \%$ & $1.3 \%$ & $13.2 \%$ & $18.7 \%$ & 1.0 & 0.1 & 0.7 & 1.3 & 5.5 & 0.4 & 4.5 & 6.5 \\
\hline \multicolumn{2}{|c|}{ All countries } & 3,940 & $14.0 \%$ & $3.7 \%$ & $3.6 \%$ & $22.8 \%$ & 0.6 & 0.5 & -1.5 & 1.8 & 4.9 & 0.9 & 3.1 & 8.8 \\
\hline
\end{tabular}

Source: Summary statistics of daily data from July 1, 2009, and June 30, 2011. Implied volatility, crash risk, and tail risk are calculated as the standard deviation, skewness, and kurtosis, respectively, of risk-neutral densities extracted from 12-month currency options using the Malz method. All currencies are quoted against the USD. 
Table 4: Policy Changes in Capital Controls and Prudential FX Measures between July 1, 2009, and June 30, 2011

\section{Capital Controls}

Prudential FX Measures

\begin{tabular}{cccccc}
\hline Quantity-based & Time-based & Price-based & FX & Other FX assets & \\
Nonresid. Residents & Nonresid. Residents & Nonresid. Residents & derivatives & and liabilities
\end{tabular}

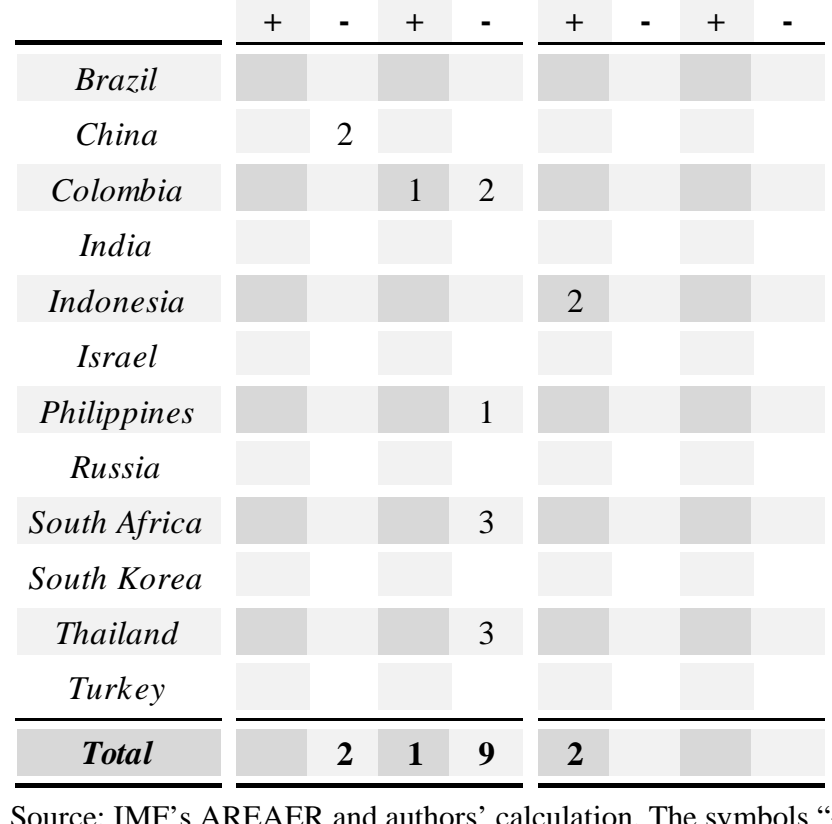

$+\quad+\quad-$

$\begin{array}{llll}+ & - & + & - \\ 9 & 1\end{array}$

$+\frac{+}{1} \frac{}{12}$

2

\begin{tabular}{|l|l|l|}
\hline & & $\mathbf{5}$ \\
\hline 4 & 1 & $\mathbf{5}$ \\
\hline 3 & 1 & $\mathbf{6}$ \\
\hline
\end{tabular}

1 1
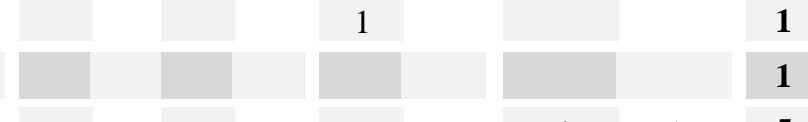


\section{Table 5: Effect of policy changes in capital controls and prudential FX measures on exchange rate volatility, crash risk, and tail risk - Baseline regression}

\begin{tabular}{|c|c|c|c|c|c|c|c|c|c|}
\hline \multirow[b]{2}{*}{ Dependent variable: } & \multicolumn{3}{|c|}{ 3-month maturity } & \multicolumn{3}{|c|}{ 6-month maturity } & \multicolumn{3}{|c|}{ 12-month maturity } \\
\hline & Volatility & Crash Risk & Tail Risk & Volatility & Crash Risk & Tail Risk & Volatility & Crash Risk & Tail Risk \\
\hline $\begin{array}{l}\text { Capital Controls - Price-based } \\
\text { (nonresidents) }\end{array}$ & $\begin{array}{c}-0.025 * * * \\
(0.005)\end{array}$ & $\begin{array}{l}-0.038^{*} \\
(0.022)\end{array}$ & $\begin{array}{c}0.015^{* * *} \\
(0.002)\end{array}$ & $\begin{array}{c}-0.021 * * * \\
(0.004)\end{array}$ & $\begin{array}{l}-0.026 \\
(0.019)\end{array}$ & $\begin{array}{l}0.020^{* * *} \\
(0.002)\end{array}$ & $\begin{array}{c}-0.016 * * * \\
(0.004)\end{array}$ & $\begin{array}{l}-0.017 \\
(0.019)\end{array}$ & $\begin{array}{c}0.018^{* * *} \\
(0.002)\end{array}$ \\
\hline $\begin{array}{c}\text { Capital Controls - Quantity- } \\
\text { based (nonresidents) }\end{array}$ & $\begin{array}{l}-0.313^{* * *} \\
(0.016)\end{array}$ & $\begin{array}{c}0.360^{* * *} \\
(0.091)\end{array}$ & $\begin{array}{c}0.431^{* * *} \\
(0.011)\end{array}$ & $\begin{array}{c}-0.139 * * * \\
(0.015)\end{array}$ & $\begin{array}{c}0.077 \\
(0.090)\end{array}$ & $\begin{array}{c}0.302^{* * *} \\
(0.012)\end{array}$ & $\begin{array}{c}0.085^{* * *} \\
(0.014)\end{array}$ & $\begin{array}{l}-0.069 \\
(0.098)\end{array}$ & $\begin{array}{c}0.174^{* * *} \\
(0.012)\end{array}$ \\
\hline $\begin{array}{c}\text { Capital Controls - Time-based } \\
\text { (nonresidents) }\end{array}$ & $\begin{array}{c}-0.238 * * * \\
(0.017)\end{array}$ & $\begin{array}{c}0.096 \\
(0.079)\end{array}$ & $\begin{array}{c}0.113^{* * *} \\
(0.011)\end{array}$ & $\begin{array}{c}-0.176 * * * \\
(0.015)\end{array}$ & $\begin{array}{c}0.062 \\
(0.077)\end{array}$ & $\begin{array}{c}0.123^{* * *} \\
(0.012)\end{array}$ & $\begin{array}{c}-0.145^{* * *} \\
(0.015)\end{array}$ & $\begin{array}{l}-0.050 \\
(0.074)\end{array}$ & $\begin{array}{c}0.090 * * * \\
(0.012)\end{array}$ \\
\hline $\begin{array}{c}\text { Capital Controls - Quantity- } \\
\text { based (residents) }\end{array}$ & $\begin{array}{c}0.037 \\
(0.023)\end{array}$ & $\begin{array}{c}0.811^{* * *} \\
(0.297)\end{array}$ & $\begin{array}{c}0.067 * * * \\
(0.016)\end{array}$ & $\begin{array}{c}0.044^{* *} \\
(0.020)\end{array}$ & $\begin{array}{c}0.775 * * * \\
(0.262)\end{array}$ & $\begin{array}{c}0.071^{* * *} \\
(0.014)\end{array}$ & $\begin{array}{c}0.061^{* * *} \\
(0.018)\end{array}$ & $\begin{array}{c}0.543^{* * *} \\
(0.118)\end{array}$ & $\begin{array}{c}0.072 * * * \\
(0.013)\end{array}$ \\
\hline $\begin{array}{c}\text { Prudential FX Measures - FX } \\
\text { Derivatives }\end{array}$ & $\begin{array}{l}-0.021 \\
(0.029)\end{array}$ & $\begin{array}{l}0.312^{* *} \\
(0.139)\end{array}$ & $\begin{array}{c}0.030^{* * *} \\
(0.009)\end{array}$ & $\begin{array}{l}-0.008 \\
(0.026)\end{array}$ & $\begin{array}{l}0.246^{* *} \\
(0.115)\end{array}$ & $\begin{array}{c}0.025^{* * *} \\
(0.008)\end{array}$ & $\begin{array}{c}0.008 \\
(0.022)\end{array}$ & $\begin{array}{l}0.100^{*} \\
(0.056)\end{array}$ & $\begin{array}{c}0.018^{* * *} \\
(0.006)\end{array}$ \\
\hline $\begin{array}{c}\text { Prudential FX Measures - } \\
\text { Other FX Assets and Liabilities }\end{array}$ & $\begin{array}{c}0.006 \\
(0.012)\end{array}$ & $\begin{array}{c}-0.217^{* * *} \\
(0.076)\end{array}$ & $\begin{array}{c}-0.021^{* * *} \\
(0.006)\end{array}$ & $\begin{array}{c}0.000 \\
(0.011)\end{array}$ & $\begin{array}{c}-0.217^{* * *} \\
(0.067)\end{array}$ & $\begin{array}{c}-0.026^{* * *} \\
(0.006)\end{array}$ & $\begin{array}{l}-0.009 \\
(0.009)\end{array}$ & $\begin{array}{c}-0.177^{* * *} \\
(0.042)\end{array}$ & $\begin{array}{c}-0.032^{* * *} \\
(0.007)\end{array}$ \\
\hline Number of observations: & 12,409 & 12,409 & 12,409 & 12,423 & 12,423 & 12,423 & 12,425 & 12,425 & 12,425 \\
\hline$R^{2}$ & $94.6 \%$ & $60.2 \%$ & $81.9 \%$ & $95.8 \%$ & $60.5 \%$ & $84.2 \%$ & $95.8 \%$ & $64.1 \%$ & $86.4 \%$ \\
\hline
\end{tabular}

Note: Daily data from July 1, 2009, to June 30, 2011, for 25 countries. Regressions also include time and country fixed effects, which are not reported in the table. Robust standard errors clustered by country and date under coefficients. The symbols *, **, and $* * *$ denote that the individual coefficient is statistically significant at the $10 \%, 5 \%$, and $1 \%$ significance level, respectively. 
Table 6: Effect of policy changes in capital controls and prudential FX measures on exchange rate volatility, crash risk, and tail risk - Disaggregation at country level

\begin{tabular}{|c|c|c|c|c|c|c|c|c|c|}
\hline \multirow[b]{2}{*}{ epc } & \multicolumn{3}{|c|}{ 3-month maturity } & \multicolumn{3}{|c|}{ 6-month maturity } & \multicolumn{3}{|c|}{ 12-month maturity } \\
\hline & $y$ & Crash Risk & Tail Risk & lity & Crash Risk & Tail Risk & latility & Crash Risk & Tail Risk \\
\hline $\begin{array}{c}\text { Capital Controls - Price- } \\
\text { Based - Brazil (nonresidents) }\end{array}$ & $\begin{array}{c}-0.036^{* * *} \\
(0.008)\end{array}$ & $\begin{array}{c}-0.162^{* *} \\
(0.067)\end{array}$ & $\begin{array}{c}0.008 \\
(0.006)\end{array}$ & $\begin{array}{c}-0.029 * * * \\
(0.006)\end{array}$ & $(0.065)$ & $\begin{array}{c}0.021^{* * *} \\
(0.006)\end{array}$ & $\begin{array}{l}-0.018^{* * *} \\
(0.006)\end{array}$ & $(0.071)$ & $\begin{array}{l}0.014^{* *} \\
(0.007)\end{array}$ \\
\hline $\begin{array}{l}\text { Capital } \\
\text { based - } C\end{array}$ & $\begin{array}{c}-0.314^{* * *} \\
(0.018)\end{array}$ & $(0.098)$ & $(0.011)$ & $\begin{array}{l}-0.139 * * * \\
(0.016)\end{array}$ & $\begin{array}{c}0.075 \\
(0.095)\end{array}$ & ** & $\begin{array}{l}0.086^{* * *} \\
(0.015)\end{array}$ & .063 & $\begin{array}{c}0.177^{* * *} \\
(0.013)\end{array}$ \\
\hline $\begin{array}{l}\text { Capital Controls - Time-based } \\
\text { - Indonesia (nonresidents) }\end{array}$ & $\begin{array}{c}-0.240^{* * *} \\
(0.019)\end{array}$ & $\begin{array}{c}0.070 \\
(0.089)\end{array}$ & $\begin{array}{c}0.109^{* * *} \\
(0.012)\end{array}$ & $\begin{array}{c}-0.179 * * * \\
(0.017)\end{array}$ & $\begin{array}{c}0.030 \\
(0.090)\end{array}$ & $\begin{array}{l}0.115^{* * *} \\
(0.013)\end{array}$ & $\begin{array}{l}-0.150^{* * *} \\
(0.017)\end{array}$ & $\begin{array}{l}-0.095 \\
(0.087)\end{array}$ & $\begin{array}{l}0.078^{* * *} \\
(0.013)\end{array}$ \\
\hline $\begin{array}{l}\text { Capital } \\
\text { based - }\end{array}$ & $\begin{array}{c}-0.176^{* * *} \\
(0.022)\end{array}$ & & $\begin{array}{c}0.104^{* * *} \\
(0.015)\end{array}$ & $\begin{array}{c}-0.144^{* * *} \\
(0.020)\end{array}$ & $\begin{array}{c}0.132 \\
(0.176)\end{array}$ & $\begin{array}{l}\text {;*** } \\
12)\end{array}$ & ** & & $\begin{array}{l}1 * * * \\
12)\end{array}$ \\
\hline $\begin{array}{l}\text { Capital Controls } \\
\text { based-Philippin }\end{array}$ & $\begin{array}{c}0.038 \\
(0.024)\end{array}$ & $\begin{array}{c}0.307^{* * *} \\
(0.098)\end{array}$ & $(0.0$ & $\begin{array}{l}0.039 * \\
(0.021)\end{array}$ & $\begin{array}{c}0.305^{* * *} \\
(0.090)\end{array}$ & 7) & $\begin{array}{l}0.044^{* *} \\
(0.018)\end{array}$ & $\begin{array}{l}0.336^{* * *} \\
(0.088)\end{array}$ & $\begin{array}{c}0.127^{* * *} \\
(0.017)\end{array}$ \\
\hline $\begin{array}{l}\text { Capita } \\
\text { based }\end{array}$ & $\begin{array}{c}0.004 \\
(0.010)\end{array}$ & $(0.085)$ & $\begin{array}{l}0.038 * * * \\
(0.009)\end{array}$ & & $\begin{array}{c}0.284^{* * *} \\
(0.081)\end{array}$ & $\begin{array}{l}0.023^{* * *} \\
(0.009)\end{array}$ & $\begin{array}{l}0.024 * * * \\
(0.008)\end{array}$ & $\begin{array}{l}0.253^{* * *} \\
(0.088)\end{array}$ & $\begin{array}{c}0.010 \\
(0.008)\end{array}$ \\
\hline $\begin{array}{l}\text { Capital } \\
\text { based - }\end{array}$ & 0 & $(0.0$ & $\begin{array}{r}0.04 \\
(0 .\end{array}$ & ) & $\begin{array}{c}1.664^{* * *} \\
(0.048)\end{array}$ & 0) & e** & $\begin{array}{c}0.716^{* * *} \\
(0.041)\end{array}$ & $\begin{array}{c}0.077^{* * *} \\
(0.010)\end{array}$ \\
\hline $\begin{array}{r}\text { Prudential } \\
\text { Derivc }\end{array}$ & 031) & $\begin{array}{c}1.136^{* * * *} \\
(0.341)\end{array}$ & & & $\begin{array}{l}* * \\
9)\end{array}$ & & $\begin{array}{l}0 . \\
(0 .\end{array}$ & $\begin{array}{l}7 * * \\
52)\end{array}$ & $\begin{array}{l}21 \\
31)\end{array}$ \\
\hline $\begin{array}{r}\text { Prudential FX } \\
\text { Derivatives }\end{array}$ & $\begin{array}{c}-0.196^{* * *} \\
(0.021)\end{array}$ & $\begin{array}{l}-0.165 \\
(0.114)\end{array}$ & $\begin{array}{l}1 * * \\
14)\end{array}$ & $\begin{array}{c}-0.164^{* * *} \\
(0.019)\end{array}$ & $\begin{array}{l}-0.154 \\
(0.130)\end{array}$ & & $\begin{array}{l}133^{* * *} \\
.019)\end{array}$ & $\begin{array}{c}-0.246 * * \\
(0.113)\end{array}$ & $\begin{array}{c}0.047^{* * *} \\
(0.014)\end{array}$ \\
\hline $\begin{array}{r}\text { Prudential Fl } \\
\text { Derivati }\end{array}$ & $\begin{array}{c}0.150^{* * *} \\
(0.024)\end{array}$ & $\begin{array}{c}0.595^{* * *} \\
(0.099)\end{array}$ & & $\begin{array}{l}0.1^{* * *} \\
(0.021)\end{array}$ & $\begin{array}{c}0.483 * * * \\
(0.090)\end{array}$ & & $\begin{array}{c}0.062^{* * *} \\
(0.018)\end{array}$ & $\begin{array}{c}0.451^{* * *} \\
(0.088)\end{array}$ & $\begin{array}{c}0.012 \\
(0.017)\end{array}$ \\
\hline $\begin{array}{r}\text { Prudential } \\
\text { Derivati }\end{array}$ & $\begin{array}{r}-0.0 \\
(0.1\end{array}$ & $\begin{array}{l}0 . \\
(0 .\end{array}$ & $\begin{array}{r}0.0 \\
(0 .\end{array}$ & 1) & & & & ) & $\begin{array}{c}0.009 \\
(0.008)\end{array}$ \\
\hline $\begin{array}{r}\text { Prudential FX } \\
\text { Derivative }\end{array}$ & $\begin{array}{c}-0.045^{* *} \\
(0.022)\end{array}$ & $\begin{array}{c}0.062 \\
(0.121)\end{array}$ & $\begin{array}{c}0.054^{* * *} \\
(0.013)\end{array}$ & $\begin{array}{l}-0.017 \\
(0.014)\end{array}$ & $\begin{array}{l}-0.143 \\
(0.123)\end{array}$ & & $\begin{array}{l}-0.012 \\
(0.013)\end{array}$ & $\begin{array}{c}0.109 \\
(0.127)\end{array}$ & $\begin{array}{l}-0.002 \\
(0.013)\end{array}$ \\
\hline $\begin{array}{r}\text { PFXM - Other } \\
\text { Liabilitie }\end{array}$ & $\begin{array}{c}0.069 * * * \\
(0.021)\end{array}$ & $\begin{array}{c}-0.182 * * \\
(0.087)\end{array}$ & $\begin{array}{r}-0.0 \\
(0 .\end{array}$ & & & & $\begin{array}{l}-0.020 \\
(0.015)\end{array}$ & & $\begin{array}{c}0.013 \\
(0.010)\end{array}$ \\
\hline $\begin{array}{c}\text { PFXM - Other FX Assets and } \\
\text { Liabilities - India }\end{array}$ & $\begin{array}{l}-0.020 * * \\
(0.008)\end{array}$ & $\begin{array}{c}-0.088^{* *} \\
(0.043)\end{array}$ & -0.008 & $\begin{array}{c}-0.025^{* * *} \\
(0.007)\end{array}$ & $\begin{array}{c}-0.101^{* *} \\
(0.046)\end{array}$ & $\begin{array}{c}-0.019 * * * \\
(0.006)\end{array}$ & $\begin{array}{c}-0.026^{* * *} \\
(0.007)\end{array}$ & $\begin{array}{c}-0.148^{* * *} \\
(0.048)\end{array}$ & $\begin{array}{c}-0.034^{* * *} \\
(0.006)\end{array}$ \\
\hline $\begin{array}{r}\text { PFXM - Otl } \\
\text { Liabiliti }\end{array}$ & $\begin{array}{l}0.023^{* *} \\
(0.010)\end{array}$ & $\begin{array}{l}-0.0 \\
(0 .\end{array}$ & $\begin{array}{r}-0.0 \\
(0 .\end{array}$ & 9) & 7) & & 3) & 3 & $\begin{array}{l}1 * \\
06)\end{array}$ \\
\hline $\begin{array}{r}P F X M \text { - Other FX As } \\
\text { Liabilities - Rus }\end{array}$ & $\begin{array}{c}-0.049^{* * *} \\
(0.012)\end{array}$ & $\begin{array}{l}-0.241^{* * *} \\
(0.046)\end{array}$ & $\begin{array}{r}-0.06 \\
(0.0\end{array}$ & $\begin{array}{l}-0.06^{* * *} \\
(0.009)\end{array}$ & $\begin{array}{c}-0.264^{* * *} \\
(0.043)\end{array}$ & $\begin{array}{l}-0.065^{* * *} \\
(0.007)\end{array}$ & $\begin{array}{l}-0.068^{* * *} \\
(0.008)\end{array}$ & $\begin{array}{l}-0.266 * * * \\
(0.047)\end{array}$ & $\begin{array}{c}-0.055^{* * *} \\
(0.007)\end{array}$ \\
\hline $\begin{array}{c}\text { PFXM - Other FX Assets and } \\
\text { Liabilities - South Africa }\end{array}$ & $\begin{array}{l}0.014^{* *} \\
(0.006)\end{array}$ & $\begin{array}{c}-0.084^{* *} \\
(0.035)\end{array}$ & $\begin{array}{l}-0.013^{*} \\
(0.007)\end{array}$ & $\begin{array}{c}0.011^{* *} \\
(0.005)\end{array}$ & $\begin{array}{l}-0.057^{*} \\
(0.033)\end{array}$ & $\begin{array}{c}0.000 \\
(0.005)\end{array}$ & $\begin{array}{c}0.008 \\
(0.005)\end{array}$ & $\begin{array}{l}-0.013 \\
(0.032)\end{array}$ & $\begin{array}{l}0.010^{* *} \\
(0.004)\end{array}$ \\
\hline $\begin{array}{l}\text { PFXM - Other FX Assets and } \\
\text { Liabilities - South Korea }\end{array}$ & $\begin{array}{c}0.047^{* * *} \\
(0.009)\end{array}$ & $\begin{array}{l}-0.035 \\
(0.030)\end{array}$ & $\begin{array}{l}-0.013^{* * *} \\
(0.004)\end{array}$ & $\begin{array}{l}0.037 * * * \\
(0.009)\end{array}$ & $\begin{array}{l}-0.029 \\
(0.042)\end{array}$ & $\begin{array}{l}-0.020 * * * \\
(0.005)\end{array}$ & $\begin{array}{l}0.029 * * * \\
(0.009)\end{array}$ & $\begin{array}{l}-0.071^{*} \\
(0.036)\end{array}$ & $\begin{array}{l}-0.025^{* * *} \\
(0.006)\end{array}$ \\
\hline $\begin{array}{c}\text { PFXM - Other FX Assets and } \\
\text { Liabilities - Turkey }\end{array}$ & $\begin{array}{l}0.022^{* *} \\
(0.009)\end{array}$ & $\begin{array}{l}-0.144 * * * \\
(0.045)\end{array}$ & $\begin{array}{c}-0.029 * * * \\
(0.006)\end{array}$ & $\begin{array}{c}0.01 \\
(0.008)\end{array}$ & $\begin{array}{c}-0.177 * * * \\
(0.044)\end{array}$ & $\begin{array}{c}-0.041 * * * \\
(0.006)\end{array}$ & $\begin{array}{l}-0.008 \\
(0.008)\end{array}$ & $\begin{array}{l}-0.208^{* * *} \\
(0.042)\end{array}$ & $\begin{array}{c}-0.049 * * * \\
(0.006)\end{array}$ \\
\hline 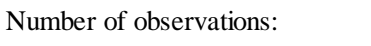 & (4) & 12,409 & 12,403 & 12,423 & $12,4<3$ & $12,4<3$ & 12,425 & 12,425 & 12,425 \\
\hline & $5.0 \%$ & 33.4\% & $82.5 \%$ & $96.1 \%$ & $63.1 \%$ & $84.7 \%$ & $96.1 \%$ & $64.8 \%$ & $86.8 \%$ \\
\hline
\end{tabular}

Note: Daily data from July 1, 2009, to June 30, 2011, for 25 countries. Regressions also include time and country fixed effects, which are not reported in the table. Robust standard errors clustered by country and date under coefficients. The symbols *, **, and $* * *$ denote that the individual coefficient is statistically significant at the $10 \%, 5 \%$, and $1 \%$ significance level, respectively. 
Table 7: Effect of policy changes in capital controls and prudential FX measures on exchange rate volatility, crash risk, and tail risk - Non-European countries

\begin{tabular}{|c|c|c|c|c|c|c|c|c|c|}
\hline \multirow[b]{2}{*}{ Dependent variable: } & \multicolumn{3}{|c|}{ 3-month maturity } & \multicolumn{3}{|c|}{ 6-month maturity } & \multicolumn{3}{|c|}{ 12-month maturity } \\
\hline & Volatility & Crash Risk & Tail Risk & Volatility & Crash Risk & Tail Risk & Volatility & Crash Risk & Tail Risk \\
\hline $\begin{array}{c}\text { Capital Controls - Price-based } \\
\text { (nonresidents) }\end{array}$ & $\begin{array}{c}-0.022^{* * *} \\
(0.006)\end{array}$ & $\begin{array}{l}-0.045^{*} \\
(0.026)\end{array}$ & $\begin{array}{c}0.013^{* * *} \\
(0.003)\end{array}$ & $\begin{array}{c}-0.019 * * * \\
(0.005)\end{array}$ & $\begin{array}{l}-0.026 \\
(0.021)\end{array}$ & $\begin{array}{c}0.018^{* * *} \\
(0.003)\end{array}$ & $\begin{array}{c}-0.014 * * * \\
(0.004)\end{array}$ & $\begin{array}{l}-0.012 \\
(0.019)\end{array}$ & $\begin{array}{c}0.015^{* * *} \\
(0.003)\end{array}$ \\
\hline $\begin{array}{l}\text { Capital Controls - Quantity- } \\
\text { based (nonresidents) }\end{array}$ & $\begin{array}{c}-0.334^{* * *} \\
(0.021)\end{array}$ & $\begin{array}{c}0.397 * * * \\
(0.132)\end{array}$ & $\begin{array}{c}0.441^{* * *} \\
(0.016)\end{array}$ & $\begin{array}{c}-0.156^{* * *} \\
(0.019)\end{array}$ & $\begin{array}{c}0.071 \\
(0.107)\end{array}$ & $\begin{array}{c}0.320 * * * \\
(0.016)\end{array}$ & $\begin{array}{c}0.069 * * * \\
(0.018)\end{array}$ & $\begin{array}{l}-0.103 \\
(0.095)\end{array}$ & $\begin{array}{l}0.195^{* * *} \\
(0.016)\end{array}$ \\
\hline $\begin{array}{l}\text { Capital Controls - Time-based } \\
\text { (nonresidents) }\end{array}$ & $\begin{array}{c}-0.213^{* * *} \\
(0.022)\end{array}$ & $\begin{array}{c}0.068 \\
(0.122)\end{array}$ & $\begin{array}{l}0.101^{* * *} \\
(0.017)\end{array}$ & $\begin{array}{c}-0.156^{* * *} \\
(0.020)\end{array}$ & $\begin{array}{c}0.059 \\
(0.107)\end{array}$ & $\begin{array}{c}0.101^{* * *} \\
(0.015)\end{array}$ & $\begin{array}{c}-0.126 * * * \\
(0.020)\end{array}$ & $\begin{array}{l}-0.041 \\
(0.086)\end{array}$ & $\begin{array}{c}0.063^{* * *} \\
(0.014)\end{array}$ \\
\hline $\begin{array}{l}\text { Capital Controls - Quantity- } \\
\text { based (residents) }\end{array}$ & $\begin{array}{c}0.016 \\
(0.027)\end{array}$ & $\begin{array}{c}0.863^{* * *} \\
(0.307)\end{array}$ & $\begin{array}{c}0.070^{* * *} \\
(0.017)\end{array}$ & $\begin{array}{c}0.025 \\
(0.024)\end{array}$ & $\begin{array}{l}0.777 * * * \\
(0.271)\end{array}$ & $\begin{array}{c}0.080^{* * *} \\
(0.016)\end{array}$ & $\begin{array}{l}0.041^{*} \\
(0.022)\end{array}$ & $\begin{array}{c}0.496 * * * \\
(0.125)\end{array}$ & $\begin{array}{c}0.085^{* * *} \\
(0.015)\end{array}$ \\
\hline $\begin{array}{c}\text { Prudential FX Measures - FX } \\
\text { Derivatives }\end{array}$ & $\begin{array}{r}-0.016 \\
(0.031)\end{array}$ & $\begin{array}{l}0.329 * \\
(0.177)\end{array}$ & $\begin{array}{l}0.021^{* *} \\
(0.008)\end{array}$ & $\begin{array}{l}-0.006 \\
(0.027)\end{array}$ & $\begin{array}{l}0.256^{*} \\
(0.147)\end{array}$ & $\begin{array}{l}0.011^{*} \\
(0.006)\end{array}$ & $\begin{array}{c}0.007 \\
(0.022)\end{array}$ & $\begin{array}{c}0.087 \\
(0.070)\end{array}$ & $\begin{array}{c}0.005 \\
(0.009)\end{array}$ \\
\hline $\begin{array}{l}\text { Prudential FX Measures - } \\
\text { Other FX Assets and Liabilities }\end{array}$ & $\begin{array}{c}0.012 \\
(0.015)\end{array}$ & $\begin{array}{c}-0.249 * * \\
(0.111)\end{array}$ & $\begin{array}{c}-0.016^{* * *} \\
(0.005)\end{array}$ & $\begin{array}{c}0.008 \\
(0.014)\end{array}$ & $\begin{array}{c}-0.225^{* *} \\
(0.097)\end{array}$ & $\begin{array}{c}-0.020^{* * *} \\
(0.005)\end{array}$ & $\begin{array}{c}0.001 \\
(0.011)\end{array}$ & $\begin{array}{c}-0.149 * * * \\
(0.048)\end{array}$ & $\begin{array}{c}-0.028^{* * *} \\
(0.008)\end{array}$ \\
\hline Number of observations: & 7,929 & 7,929 & 7,929 & 7,946 & 7,946 & 7,946 & 7,957 & 7,957 & 7,957 \\
\hline$R^{2}$ & $94.8 \%$ & $56.3 \%$ & $76.0 \%$ & $96.3 \%$ & $57.7 \%$ & $78.5 \%$ & $96.5 \%$ & $65.1 \%$ & $81.7 \%$ \\
\hline
\end{tabular}

Note: Daily data from July 1, 2009, to June 30, 2011, for 16 non-European countries. Regressions also include time and country fixed effects, which are not reported in the table. Robust standard errors clustered by country and date under coefficients. The symbols $* * *$, and $* * *$ denote that the individual coefficient is statistically significant at the $10 \%, 5 \%$, and $1 \%$ significance level, respectively. 
Table 8: Effect of policy changes in capital controls and prudential FX measures on exchange rate volatility, crash risk, and tail risk - Emerging markets

\begin{tabular}{|c|c|c|c|c|c|c|c|c|c|}
\hline \multirow[b]{2}{*}{ Dependent variable: } & \multicolumn{3}{|c|}{ 3-month maturity } & \multicolumn{3}{|c|}{ 6-month maturity } & \multicolumn{3}{|c|}{ 12-month maturity } \\
\hline & Volatility & Crash Risk & Tail Risk & Volatility & Crash Risk & Tail Risk & Volatility & Crash Risk & Tail Risk \\
\hline $\begin{array}{c}\text { Capital Controls - Price-based } \\
\text { (nonresidents) }\end{array}$ & $\begin{array}{c}-0.020 * * * \\
(0.005)\end{array}$ & $\begin{array}{c}0.014 \\
(0.018)\end{array}$ & $\begin{array}{c}0.019 * * * \\
(0.004)\end{array}$ & $\begin{array}{c}-0.018^{* * *} \\
(0.005)\end{array}$ & $\begin{array}{l}0.027^{*} \\
(0.016)\end{array}$ & $\begin{array}{c}0.025^{* * *} \\
(0.004)\end{array}$ & $\begin{array}{c}-0.015^{* * *} \\
(0.005)\end{array}$ & $\begin{array}{c}0.039 * * * \\
(0.011)\end{array}$ & $\begin{array}{c}0.023^{* * *} \\
(0.004)\end{array}$ \\
\hline $\begin{array}{l}\text { Capital Controls - Quantity- } \\
\text { based (nonresidents) }\end{array}$ & $\begin{array}{c}-0.333^{* * *} \\
(0.021)\end{array}$ & $\begin{array}{c}0.100 \\
(0.077)\end{array}$ & $\begin{array}{l}0.408 * * * \\
(0.018)\end{array}$ & $\begin{array}{c}-0.153^{* * *} \\
(0.021)\end{array}$ & $\begin{array}{c}-0.194^{* * *} \\
(0.074)\end{array}$ & $\begin{array}{c}0.277 * * * \\
(0.020)\end{array}$ & $\begin{array}{c}0.075^{* * *} \\
(0.022)\end{array}$ & $\begin{array}{c}-0.354^{* * *} \\
(0.066)\end{array}$ & $\begin{array}{l}0.15^{* * *} \\
(0.020)\end{array}$ \\
\hline $\begin{array}{l}\text { Capital Controls - Time-based } \\
\text { (nonresidents) }\end{array}$ & $\begin{array}{c}-0.213^{* * *} \\
(0.022)\end{array}$ & $\begin{array}{c}0.307 * * * \\
(0.092)\end{array}$ & $\begin{array}{c}0.135^{* * *} \\
(0.019)\end{array}$ & $\begin{array}{c}-0.158^{* * *} \\
(0.022)\end{array}$ & $\begin{array}{l}0.281^{* * *} \\
(0.090)\end{array}$ & $\begin{array}{c}0.146 * * * \\
(0.020)\end{array}$ & $\begin{array}{c}-0.131^{* * *} \\
(0.023)\end{array}$ & $\begin{array}{l}0.179 * * \\
(0.074)\end{array}$ & $\begin{array}{c}0.111^{* * *} \\
(0.019)\end{array}$ \\
\hline $\begin{array}{c}\text { Capital Controls - Quantity- } \\
\text { based (residents) }\end{array}$ & $\begin{array}{c}0.010 \\
(0.024)\end{array}$ & $\begin{array}{l}0.539 * \\
(0.318)\end{array}$ & $\begin{array}{l}0.042^{* *} \\
(0.021)\end{array}$ & $\begin{array}{c}0.027 \\
(0.022)\end{array}$ & $\begin{array}{l}0.493^{*} \\
(0.281)\end{array}$ & $\begin{array}{l}0.044^{* *} \\
(0.022)\end{array}$ & $\begin{array}{l}0.05^{* *} \\
(0.022)\end{array}$ & $\begin{array}{l}0.245^{* *} \\
(0.113)\end{array}$ & $\begin{array}{l}0.046^{* *} \\
(0.021)\end{array}$ \\
\hline $\begin{array}{c}\text { Prudential FX Measures - FX } \\
\text { Derivatives }\end{array}$ & $\begin{array}{l}-0.029 \\
(0.027)\end{array}$ & $\begin{array}{l}0.296 * * \\
(0.150)\end{array}$ & $\begin{array}{c}0.031^{* * *} \\
(0.011)\end{array}$ & $\begin{array}{l}-0.013 \\
(0.026)\end{array}$ & $\begin{array}{l}0.233^{*} \\
(0.119)\end{array}$ & $\begin{array}{l}0.026 * * \\
(0.011)\end{array}$ & $\begin{array}{c}0.006 \\
(0.023)\end{array}$ & $\begin{array}{l}0.076^{*} \\
(0.041)\end{array}$ & $\begin{array}{l}0.018^{* *} \\
(0.007)\end{array}$ \\
\hline $\begin{array}{l}\text { Prudential FX Measures - } \\
\text { Other FX Assets and Liabilities }\end{array}$ & $\begin{array}{c}0.016 \\
(0.013)\end{array}$ & $\begin{array}{l}-0.123 \\
(0.082)\end{array}$ & $\begin{array}{l}-0.013^{*} \\
(0.008)\end{array}$ & $\begin{array}{c}0.006 \\
(0.012)\end{array}$ & $\begin{array}{l}-0.120 \\
(0.073)\end{array}$ & $\begin{array}{c}-0.017^{* *} \\
(0.007)\end{array}$ & $\begin{array}{l}-0.005 \\
(0.010)\end{array}$ & $\begin{array}{l}-0.072 * * \\
(0.031)\end{array}$ & $\begin{array}{c}-0.023 * * * \\
(0.007)\end{array}$ \\
\hline Number of observations: & 7,939 & 7,939 & 7,939 & 7,938 & 7,938 & 7,938 & 7,936 & 7,936 & 7,936 \\
\hline$R^{2}$ & $95.4 \%$ & $53.6 \%$ & $73.5 \%$ & $96.4 \%$ & $52.5 \%$ & $75.9 \%$ & $96.2 \%$ & $58.5 \%$ & $79.9 \%$ \\
\hline
\end{tabular}

Note: Daily data from July 1, 2009, to June 30, 2011, for 16 emerging markets. Regressions also include time and country fixed effects, which are not reported in the table. Robust standard errors clustered by country and date under coefficients. The symbols ${ }^{*}, * *$, and $* * *$ denote that the individual coefficient is statistically significant at the $10 \%, 5 \%$, and $1 \%$ significance level, respectively. 


\section{Table 9: Effect of policy changes in capital controls and prudential FX measures on exchange rate volatility, crash risk, and tail risk - Vanna-Volga method}

\begin{tabular}{|c|c|c|c|c|c|c|c|c|c|}
\hline \multirow[b]{2}{*}{ Dependent variable: } & \multicolumn{3}{|c|}{ 3-month maturity } & \multicolumn{3}{|c|}{ 6-month maturity } & \multicolumn{3}{|c|}{ 12-month maturity } \\
\hline & Volatility & Crash Risk & Tail Risk & Volatility & Crash Risk & Tail Risk & Volatility & Crash Risk & Tail Risk \\
\hline $\begin{array}{c}\text { Capital Controls - Price-based } \\
\text { (nonresidents) }\end{array}$ & $\begin{array}{c}-0.049 * * * \\
(0.010)\end{array}$ & $\begin{array}{l}-0.034^{*} \\
(0.020)\end{array}$ & $\begin{array}{c}0.016^{* * *} \\
(0.004)\end{array}$ & $\begin{array}{c}-0.042^{* * *} \\
(0.008)\end{array}$ & $\begin{array}{l}-0.022 \\
(0.019)\end{array}$ & $\begin{array}{l}0.022^{* * *} \\
(0.003)\end{array}$ & $\begin{array}{c}-0.035^{* * *} \\
(0.007)\end{array}$ & $\begin{array}{l}-0.017 \\
(0.017)\end{array}$ & $\begin{array}{c}0.021^{* * *} \\
(0.003)\end{array}$ \\
\hline $\begin{array}{c}\text { Capital Controls - Quantity- } \\
\text { based (nonresidents) }\end{array}$ & $\begin{array}{l}-0.605^{* * *} \\
(0.032)\end{array}$ & $\begin{array}{c}0.477^{* * *} \\
(0.087)\end{array}$ & $\begin{array}{c}0.442^{* * *} \\
(0.012)\end{array}$ & $\begin{array}{c}-0.261^{* * *} \\
(0.029)\end{array}$ & $\begin{array}{c}0.432 * * * \\
(0.091)\end{array}$ & $\begin{array}{l}0.317 * * * \\
(0.015)\end{array}$ & $\begin{array}{c}0.163 * * * \\
(0.028)\end{array}$ & $\begin{array}{l}0.248^{* * *} \\
(0.081)\end{array}$ & $\begin{array}{c}0.140^{* * *} \\
(0.016)\end{array}$ \\
\hline $\begin{array}{c}\text { Capital Controls - Time-based } \\
\text { (nonresidents) }\end{array}$ & $\begin{array}{c}-0.495^{* * *} \\
(0.033)\end{array}$ & $\begin{array}{c}0.096 \\
(0.075)\end{array}$ & $\begin{array}{c}0.063^{* * *} \\
(0.012)\end{array}$ & $\begin{array}{c}-0.379 * * * \\
(0.030)\end{array}$ & $\begin{array}{c}0.031 \\
(0.073)\end{array}$ & $\begin{array}{l}0.062 * * * \\
(0.014)\end{array}$ & $\begin{array}{c}-0.316^{* * *} \\
(0.030)\end{array}$ & $\begin{array}{l}-0.055 \\
(0.077)\end{array}$ & $\begin{array}{c}0.041^{* * *} \\
(0.016)\end{array}$ \\
\hline $\begin{array}{c}\text { Capital Controls - Quantity- } \\
\text { based (residents) }\end{array}$ & $\begin{array}{c}0.063 \\
(0.046)\end{array}$ & $\begin{array}{l}0.71^{* * *} \\
(0.239)\end{array}$ & $\begin{array}{c}0.057 * * * \\
(0.021)\end{array}$ & $\begin{array}{l}0.079 * \\
(0.040)\end{array}$ & $\begin{array}{c}0.639 * * * \\
(0.183)\end{array}$ & $\begin{array}{l}0.071^{* * *} \\
(0.018)\end{array}$ & $\begin{array}{c}0.110^{* * *} \\
(0.035)\end{array}$ & $\begin{array}{c}0.611^{* * *} \\
(0.158)\end{array}$ & $\begin{array}{c}0.080^{* * *} \\
(0.017)\end{array}$ \\
\hline $\begin{array}{c}\text { Prudential FX Measures - FX } \\
\text { Derivatives }\end{array}$ & $\begin{array}{l}-0.045 \\
(0.059)\end{array}$ & $\begin{array}{l}0.263^{* *} \\
(0.109)\end{array}$ & $\begin{array}{c}0.020 \\
(0.019)\end{array}$ & $\begin{array}{l}-0.014 \\
(0.051)\end{array}$ & $\begin{array}{l}0.171^{* *} \\
(0.074)\end{array}$ & $\begin{array}{l}0.028^{* *} \\
(0.014)\end{array}$ & $\begin{array}{c}0.019 \\
(0.043)\end{array}$ & $\begin{array}{l}0.133^{*} \\
(0.073)\end{array}$ & $\begin{array}{c}0.026^{* * *} \\
(0.009)\end{array}$ \\
\hline $\begin{array}{l}\text { Prudential FX Measures - } \\
\text { Other FX Assets and Liabilities }\end{array}$ & $\begin{array}{c}0.016 \\
(0.025)\end{array}$ & $\begin{array}{c}-0.192 * * * \\
(0.062)\end{array}$ & $\begin{array}{l}-0.012 \\
(0.008)\end{array}$ & $\begin{array}{c}0.003 \\
(0.023)\end{array}$ & $\begin{array}{c}-0.181^{* * *} \\
(0.051)\end{array}$ & $\begin{array}{l}-0.02 * * \\
(0.008)\end{array}$ & $\begin{array}{l}-0.014 \\
(0.019)\end{array}$ & $\begin{array}{c}-0.177^{* * *} \\
(0.048)\end{array}$ & $\begin{array}{c}-0.027 * * * \\
(0.008)\end{array}$ \\
\hline Number of observations: & 12,398 & 12,398 & 12,398 & 12,419 & 12,419 & 12,419 & 12,422 & 12,422 & 12,422 \\
\hline$R^{2}$ & $94.6 \%$ & $65.7 \%$ & $84.4 \%$ & $95.7 \%$ & $67.7 \%$ & $84.8 \%$ & $95.7 \%$ & $70.0 \%$ & $86.6 \%$ \\
\hline
\end{tabular}

Note: Implied volatility, crash risk, and tail risk are calculated as the standard deviation, skewness, and kurtosis, respectively, of risk-neutral densities extracted from 12-month currency options using the Vanna-Volga method. Daily data from July 1, 2009, to June 30, 2011, for 25 countries. Regressions also include time and country fixed effects, which are not reported in the table. Robust standard errors clustered by country and date under coefficients. The symbols *, **, and *** denote that the individual coefficient is statistically significant at the $10 \%, 5 \%$, and $1 \%$ significance level, respectively. 
Table 10: Effect of policy changes in capital controls and prudential FX measures on at-themoney (ATM), 25 risk-reversal (25RR), and 25 butterfly (25BF) currency option prices

\begin{tabular}{|c|c|c|c|c|c|c|c|c|c|}
\hline \multirow[b]{2}{*}{ Dependent variable: } & \multicolumn{3}{|c|}{ 3-month maturity } & \multicolumn{3}{|c|}{ 6-month maturity } & \multicolumn{3}{|c|}{ 12-month maturity } \\
\hline & ATM & $25 R R$ & $25 B F$ & ATM & $25 R R$ & $25 B F$ & ATM & $25 R R$ & $25 B F$ \\
\hline $\begin{array}{c}\text { Capital Controls - Price-based } \\
\text { (nonresidents) }\end{array}$ & $\begin{array}{c}-0.034^{* * *} \\
(0.003)\end{array}$ & $\begin{array}{c}-0.059 * * * \\
(0.022)\end{array}$ & $\begin{array}{l}-0.003 \\
(0.006)\end{array}$ & $\begin{array}{l}-0.025^{* * *} \\
(0.005)\end{array}$ & $\begin{array}{l}-0.014 \\
(0.038)\end{array}$ & $\begin{array}{c}0.001 \\
(0.006)\end{array}$ & $\begin{array}{c}-0.019 * * * \\
(0.004)\end{array}$ & $\begin{array}{l}-0.036^{*} \\
(0.018)\end{array}$ & $\begin{array}{l}-0.003 \\
(0.007)\end{array}$ \\
\hline $\begin{array}{l}\text { Capital Controls - Quantity- } \\
\text { based (nonresidents) }\end{array}$ & $\begin{array}{l}-0.465^{* * *} \\
(0.017)\end{array}$ & $\begin{array}{l}-0.086 \\
(0.090)\end{array}$ & $\begin{array}{c}0.457 * * * \\
(0.030)\end{array}$ & $\begin{array}{c}-0.228^{* * *} \\
(0.015)\end{array}$ & $\begin{array}{l}-0.173^{*} \\
(0.099)\end{array}$ & $\begin{array}{l}0.464^{* * *} \\
(0.027)\end{array}$ & $\begin{array}{l}0.042 * * * \\
(0.016)\end{array}$ & $\begin{array}{l}-0.092 \\
(0.099)\end{array}$ & $\begin{array}{c}0.475^{* * *} \\
(0.029)\end{array}$ \\
\hline $\begin{array}{c}\text { Capital Controls - Time-based } \\
\text { (nonresidents) }\end{array}$ & $\begin{array}{l}-0.264^{* * *} \\
(0.017)\end{array}$ & $\begin{array}{c}-0.180^{* *} \\
(0.080)\end{array}$ & $\begin{array}{c}-0.086^{* * *} \\
(0.030)\end{array}$ & $\begin{array}{c}-0.205^{* * *} \\
(0.016)\end{array}$ & $\begin{array}{l}-0.161^{*} \\
(0.083)\end{array}$ & $\begin{array}{l}-0.016 \\
(0.027)\end{array}$ & $\begin{array}{c}-0.169^{* * *} \\
(0.016)\end{array}$ & $\begin{array}{c}-0.214 * * * \\
(0.079)\end{array}$ & $\begin{array}{c}-0.064^{* *} \\
(0.028)\end{array}$ \\
\hline $\begin{array}{l}\text { Capital Controls - Quantity- } \\
\text { based (residents) }\end{array}$ & $\begin{array}{c}0.017 \\
(0.019)\end{array}$ & $\begin{array}{c}0.703^{* * *} \\
(0.228)\end{array}$ & $\begin{array}{l}0.099 * \\
(0.054)\end{array}$ & $\begin{array}{l}0.043^{* *} \\
(0.020)\end{array}$ & $\begin{array}{c}0.826 * * * \\
(0.270)\end{array}$ & $\begin{array}{l}0.089 * \\
(0.047)\end{array}$ & $\begin{array}{c}0.063 * * * \\
(0.018)\end{array}$ & $\begin{array}{c}0.572 * * * \\
(0.113)\end{array}$ & $\begin{array}{l}0.112^{* *} \\
(0.045)\end{array}$ \\
\hline $\begin{array}{c}\text { Prudential FX Measures - FX } \\
\text { Derivatives }\end{array}$ & $\begin{array}{c}0.011 \\
(0.015)\end{array}$ & $\begin{array}{l}0.218^{*} \\
(0.116)\end{array}$ & $\begin{array}{c}0.027 \\
(0.028)\end{array}$ & $\begin{array}{l}-0.012 \\
(0.027)\end{array}$ & $\begin{array}{l}-0.025 \\
(0.213)\end{array}$ & $\begin{array}{c}0.047 \\
(0.030)\end{array}$ & $\begin{array}{c}0.004 \\
(0.023)\end{array}$ & $\begin{array}{l}0.104^{*} \\
(0.055)\end{array}$ & $\begin{array}{l}0.053^{*} \\
(0.028)\end{array}$ \\
\hline $\begin{array}{l}\text { Prudential FX Measures - } \\
\text { Other FX Assets and Liabilities }\end{array}$ & $\begin{array}{c}0.003 \\
(0.010)\end{array}$ & $\begin{array}{c}-0.177^{* * *} \\
(0.060)\end{array}$ & $\begin{array}{l}-0.025 \\
(0.018)\end{array}$ & $\begin{array}{c}0.002 \\
(0.011)\end{array}$ & $\begin{array}{c}-0.165^{* *} \\
(0.074)\end{array}$ & $\begin{array}{l}-0.029 \\
(0.020)\end{array}$ & $\begin{array}{l}-0.008 \\
(0.009)\end{array}$ & $\begin{array}{c}-0.172 * * * \\
(0.041)\end{array}$ & $\begin{array}{c}-0.042 * * \\
(0.020)\end{array}$ \\
\hline Number of observations: & 12,709 & 12,626 & 12,698 & 12,727 & 12,646 & 12,715 & 12,723 & 12,710 & 12,710 \\
\hline$R^{2}$ & $94.6 \%$ & $70.4 \%$ & $85.0 \%$ & $95.7 \%$ & $67.9 \%$ & $87.1 \%$ & $95.6 \%$ & $74.3 \%$ & $85.5 \%$ \\
\hline
\end{tabular}

Note: Daily data from July 1, 2009, to June 30, 2011, for 25 countries. Regressions also include time and country fixed effects, which are not reported in the table. Robust standard errors clustered by country and date under coefficients. The symbols *, **, and $* * *$ denote that the individual coefficient is statistically significant at the $10 \%, 5 \%$, and $1 \%$ significance level, respectively. 
Table 11: Effect of policy changes in capital controls and prudential FX measures on exchange rate volatility, crash risk, and tail risk - Quarterly frequency

\begin{tabular}{|c|c|c|c|c|c|c|c|c|c|}
\hline \multirow[b]{2}{*}{ Dependent variable: } & \multicolumn{3}{|c|}{ 3-month maturity } & \multicolumn{3}{|c|}{ 6-month maturity } & \multicolumn{3}{|c|}{ 12-month maturity } \\
\hline & Volatility & Crash Risk & Tail Risk & Volatility & Crash Risk & Tail Risk & Volatility & Crash Risk & Tail Risk \\
\hline $\begin{array}{c}\text { Capital Controls - Price-based } \\
\text { (nonresidents) }\end{array}$ & $\begin{array}{c}-0.026^{* * *} \\
(0.005)\end{array}$ & $\begin{array}{l}-0.046^{*} \\
(0.028)\end{array}$ & $\begin{array}{c}0.014 * * * \\
(0.003)\end{array}$ & $\begin{array}{c}-0.022 * * * \\
(0.005)\end{array}$ & $\begin{array}{l}-0.035 \\
(0.026)\end{array}$ & $\begin{array}{c}0.020^{* * *} \\
(0.002)\end{array}$ & $\begin{array}{c}-0.017 * * * \\
(0.005)\end{array}$ & $\begin{array}{l}-0.020 \\
(0.020)\end{array}$ & $\begin{array}{c}0.017^{* * *} \\
(0.002)\end{array}$ \\
\hline $\begin{array}{l}\text { Capital Controls - Quantity- } \\
\text { based (nonresidents) }\end{array}$ & $\begin{array}{c}-0.315^{* * *} \\
(0.044)\end{array}$ & $\begin{array}{l}0.518^{* *} \\
(0.222)\end{array}$ & $\begin{array}{c}0.471^{* * *} \\
(0.053)\end{array}$ & $\begin{array}{c}-0.133^{* * *} \\
(0.027)\end{array}$ & $\begin{array}{c}0.279 \\
(0.175)\end{array}$ & $\begin{array}{c}0.334 * * * \\
(0.035)\end{array}$ & $\begin{array}{c}0.097 * * * \\
(0.021)\end{array}$ & $\begin{array}{l}-0.065 \\
(0.156)\end{array}$ & $\begin{array}{c}0.193^{* * *} \\
(0.028)\end{array}$ \\
\hline $\begin{array}{c}\text { Capital Controls - Time-based } \\
\text { (nonresidents) }\end{array}$ & $\begin{array}{c}-0.253^{* * *} \\
(0.023)\end{array}$ & $\begin{array}{c}0.074 \\
(0.093)\end{array}$ & $\begin{array}{c}0.122^{* * *} \\
(0.014)\end{array}$ & $\begin{array}{c}-0.188^{* * *} \\
(0.020)\end{array}$ & $\begin{array}{c}0.042 \\
(0.102)\end{array}$ & $\begin{array}{c}0.138 * * * \\
(0.021)\end{array}$ & $\begin{array}{c}-0.156^{* * *} \\
(0.018)\end{array}$ & $\begin{array}{l}-0.069 \\
(0.104)\end{array}$ & $\begin{array}{c}0.102^{* * *} \\
(0.018)\end{array}$ \\
\hline $\begin{array}{c}\text { Capital Controls - Quantity- } \\
\text { based (residents) }\end{array}$ & $\begin{array}{c}0.046 \\
(0.034)\end{array}$ & $\begin{array}{l}1.037^{* *} \\
(0.450)\end{array}$ & $\begin{array}{c}0.084^{* * *} \\
(0.024)\end{array}$ & $\begin{array}{l}0.055^{*} \\
(0.029)\end{array}$ & $\begin{array}{c}0.984 * * \\
(0.396)\end{array}$ & $\begin{array}{c}0.091^{* * *} \\
(0.024)\end{array}$ & $\begin{array}{c}0.078^{* * *} \\
(0.027)\end{array}$ & $\begin{array}{c}0.660 * * * \\
(0.176)\end{array}$ & $\begin{array}{c}0.090 * * * \\
(0.022)\end{array}$ \\
\hline $\begin{array}{c}\text { Prudential FX Measures - FX } \\
\text { Derivatives }\end{array}$ & $\begin{array}{l}-0.023 \\
(0.032)\end{array}$ & $\begin{array}{l}0.353^{* *} \\
(0.172)\end{array}$ & $\begin{array}{c}0.033^{* * *} \\
(0.012)\end{array}$ & $\begin{array}{l}-0.009 \\
(0.029)\end{array}$ & $\begin{array}{l}0.281^{* *} \\
(0.139)\end{array}$ & $\begin{array}{c}0.028 * * * \\
(0.010)\end{array}$ & $\begin{array}{c}0.009 \\
(0.025)\end{array}$ & $\begin{array}{l}0.111^{* *} \\
(0.049)\end{array}$ & $\begin{array}{c}0.023^{* * *} \\
(0.002)\end{array}$ \\
\hline $\begin{array}{c}\text { Prudential FX Measures - } \\
\text { Other FX Assets and Liabilities }\end{array}$ & $\begin{array}{c}0.004 \\
(0.014)\end{array}$ & $\begin{array}{c}-0.272 * * \\
(0.120)\end{array}$ & $\begin{array}{c}-0.025^{* *} \\
(0.010)\end{array}$ & $\begin{array}{l}-0.003 \\
(0.011)\end{array}$ & $\begin{array}{c}-0.267 * * \\
(0.110)\end{array}$ & $\begin{array}{c}-0.031^{* * *} \\
(0.010)\end{array}$ & $\begin{array}{r}-0.013 \\
(0.008)\end{array}$ & $\begin{array}{c}-0.206 * * * \\
(0.072)\end{array}$ & $\begin{array}{c}-0.037 * * * \\
(0.010)\end{array}$ \\
\hline Number of observations: & 200 & 200 & 200 & 200 & 200 & 200 & 200 & 200 & 200 \\
\hline$R^{2}$ & $96.4 \%$ & $71.6 \%$ & $87.9 \%$ & $97.2 \%$ & $71.8 \%$ & $89.2 \%$ & $97.0 \%$ & $73.9 \%$ & $91.0 \%$ \\
\hline
\end{tabular}

Note: Quarterly data from Q3 2009 to Q2 2011 for 25 countries. Regressions also include time and country fixed effects, which are not reported in the table. Robust standard errors clustered by country and date under coefficients. The symbols *, **, and *** denote that the individual coefficient is statistically significant at the $10 \%, 5 \%$, and $1 \%$ significance level, respectively. 